\title{
Eşit, Güvenli, Özgür İlişki: Üniversite Öğrencilerine Yönelik Bir Flört Şiddeti Önleme Programının Etki Değerlendirmesi
}

\author{
An1l Özge Üstünel \\ İstanbul Bilgi Üniversitesi
}

\begin{abstract}
Özet
Bu çalışmanın amacı, üniversite öğrencilerine yönelik bir flört şiddeti önleme programı geliştirmek ve programın etki değerlendirmesini yapmaktır. İlk olarak öğrencileri flört şiddeti konusunda bilgilendirmek, şiddet içeren ve kontrolcü davranışları tanıma ve başa çıkma becerilerini desteklemek, çatışma çözme becerilerini geliştirmek, daha güvenli ve eşitlikçi ilişkiler kurmaları yönünde rehberlik etmek amacıyla 8 oturumluk grup-temelli bir program hazırlanmıştır. Hazırlanan programın içerik ve zamanlama bakımından uygunluğunu değerlendirmek için yürütülen pilot çalışmada program iki ayrı gruba uygulanmış, daha sonra gerekli değişiklikler yapılarak program son haline getirilmiştir. Asıl çalışmaya İstanbul'da bir üniversitede okuyan, yaşları 18-22 arasında değişen 90 öğrenci (deney = 41, kontrol = 49) katılmıştır. Programın etkisini değerlendirmek için deney ve kontrol gruplarına ön-test ve son-test ölçümlerinde İkili İlişkilerde Çatışma Çözme Tepkileri Ölçeği, Çelişik Duygulu Cinsiyetçilik Ölçeği ve Flört Şiddetine Yönelik Tutum Ölçekleri uygulanmıştır. Yapılan bir dizi 2 (Zaman: ön-test, son-test) x 2 (Grup: deney, kontrol) x 2 (Cinsiyet: kadın, erkek) karışık faktöriyel varyans analizi programdan sonra düşmanca cinsiyetçilik tutumu, kadının uyguladığı fiziksel şiddete yönelik kabullenici tutumlar ve erkeğin uyguladığı psikolojik şiddete yönelik kabullenici tutumlarda istatistiksel olarak anlamlı bir azalma olduğunu göstermiştir. Yapıcı çatışma çözme becerisi ve ölçülen diğer tutumlarda beklenen yönde bir değişim saptanamamıştır. Sonuçlar flört şiddetini önleme çalışmalarının kadına yönelik şiddetle mücadelede etkili bir araç olabileceğine işaret etmektedir. Programda yapılması gereken değişiklikler, çalışmanın sınırlılıkları ve sonraki araştırmalar için öneriler tartışılmıştır.
\end{abstract}

Anahtar kelimeler: Flört şiddetinin önlenmesi, üniversite öğrencileri, etki araştırması

\begin{abstract}
The present study aims to develop a dating violence prevention program for college students and to test its effectiveness. Firstly, a group-based 8-session dating violence prevention program was developed with the aim of providing information about dating violence, supporting constructive conflict resolution skills, and providing guidance for safe and equal relationships. A pilot study was conducted with 2 groups to test whether the program worked well in terms of content and timing. After the necessary revisions, the program was finalized. A total of 90 students attending a university in Istanbul (Prevention $=41$, Control $=49$ ) participated in the main study. Responses to Dissatisfaction Scale, Ambivalent Sexism Scale and Attitudes towards Dating Violence Scales were used in the pretest and posttest assessments. A series of 2 (Time: pre-test, post-test) x 2 (Group: prevention, control) x 2 (Sex: women, men) mixed factorial analyses of variance showed that there was a statistically significant decrease in support for hostile sexism, accepting attitudes towards women's use of physical violence and accepting attitudes towards men's use of psychological violence after the program. No significant changes were observed in constructive conflict resolution skills and other attitude measures. The results indicated that dating violence prevention programs can be an effective tool to combat violence against women. The revisions needed in the program, the limitations of the present study and suggestions for future work are discussed.
\end{abstract}

Keywords: Dating violence prevention, college students, effectiveness research

Yazar notu: Bu çalışmadaki rehberliğinden dolayı Prof. Güler Okman Fişek’e, çalışmaya verdikleri destek için Can Baycan, Dorukhan Açıl, Zeynep Kaboğlu, Emine Eda Çeker ve Sevi Ceren Özdemir'e, katkıları için iki anonim hakeme teşekkür ederim. Bu çalışma TÜBITTAK 2214/A Yurt Dışı Doktora Sırası Araştırma Burs Programı kapsamında desteklenmiştir.

Yazışma Adresi: Dr. Öğr. Üyesi, Anıl Özge Üstünel, İstanbul Bilgi Üniversitesi, Sosyal ve Beşeri Bilimler Fakültesi, Psikoloji Bölümü, Santralistanbul, Eski Silahtarağa Elektrik Santrali, Kazım Karabekir Cad., No: 2/13, 34060, Eyüpsultan / İstanbul

E-posta: anil.ustunel@gmail.com

Gönderim Tarihi: 18.11 .2018

Kabul Tarihi: 08.10.2019 
Flört şiddeti çok sayıda ergen ve gencin hayatını etkileyen önemli bir psikolojik ve sosyal sorundur. Yapılan çalışmalar flört şiddetinin ergen ve gençler arasında oldukça yaygın olduğuna işaret etmektedir (WHO, 2010). Oranlar ölçüm yöntemine bağlı olarak değişiklik gösterse de üniversite öğrencilerinin \% 8-37'sinin fiziksel flört şiddetine, \% 2-10'unun cinsel flört şiddetine ve \% 43-86'sının psikolojik flört şiddetine maruz kaldığ bildirilmektedir (Aba, 2008; Arslan, 2002; Besni, 2011; Murray ve Kardatzke, 2007). Bu şiddet deneyimlerinin kısa ve uzun vadede düşük okul başarısı, depresyon, anksiyete, intihar girişimi, travma sonrası stres belirtileri, yaralanma, madde ve alkol kullanımı ve cinsel yolla bulaşan hastalıklar gibi pek çok akademik, fiziksel ve psikolojik riskle ilişkili olduğu bulunmuştur (Dikmen, Özaydın ve Yılmaz, 2018; Eshelman ve Levendosky, 2012; Foshee, Reyes, Gottfredson, Chang ve Ennett, 2013; Oswalt, Wyatt ve Ochoa, 2018; Teten, Ball, Valle, Noonan ve Rosenbluth, 2009). Flört şiddetinin yaygınlığ1 ve doğurduğu ciddi riskler fark edildikçe, hem akademik hem de sivil toplum alanında bu sorunun sistematik bir şekilde araştırılması ve önlenmesi için yapılan çalışmalar ivme kazanmaya başlamış, çeşitli ülkelerde ortaokul, lise ve üniversite öğrencilerine yönelik önleme programları geliştirilmiştir (Violence Prevention Alliance, 2012; WHO, 2010).

Bu uluslararası gelişmelere paralel olarak ülkemizde de flört şiddetiyle ilgili araştırmaların sayısı son yıllarda artmış ve flört şiddetinin gençler arasında yaygın bir sorun olduğu ortaya konulmuştur (Kepir-Savoly, Ulaş ve Demirtaş-Zorbaz, 2014; Selçuk, Avc1 ve Mercan, 2018; Toplu-Demirtaş, Hatipoğlu-Sümer ve White, 2013). Araştırmacılar flört şiddeti konusunda bilgilendirici ve farkındalık artırıcı çalışmaların gerekliliğine vurgu yapmaktadır (Aslan, Vefikulucay, Zeyneloğlu, Erdost ve Temel, 2008; Kılınçer ve Tuzgöl-Dost, 2014). Son y1llarda bu yönde çeşitli çabalar olsa da (Özdere ve Kürtül, 2017) ulusal alan yazına bakıldığında henüz etkinliği sınanmış ve kapsamlı bir flört şiddeti önleme programının olmadığ1 görülmektedir. Bu araştırma üniversite öğrencilerinin flört ilişkilerinde şiddetin önlenmesini hedefleyen bir program geliştirerek ve bu programın etki değerlendirmesini yaparak alan yazındaki bu boşluğu doldurmayı hedeflemektedir.

\section{Flört Şiddetini Önleme Çalışmaları}

Flört şiddeti partneri kontrol etmek veya partnere fiziksel, cinsel ya da psikolojik bakımdan zarar vermek amacıyla yapılan, partnerin kişisel bütünlük ve gelişimini engelleyen veya tehdit eden tüm davranışlar olarak tanımlanabilir (Cornelius ve Resseguie, 2007; Pittman, Wolfe ve Wekerle, 2000; Theriot, 2008; Wekerle ve Wolfe, 1999). Flört şiddetinin başlıca biçimleri fiziksel, cinsel, psikolojik, dijital flört şiddeti ve 1srarlı takip davranışıdır (Murray ve Kardatzke, 2007; Reed, Tolman ve Ward, 2016; Shorey, Cornelius ve Bell, 2008). Alan yazına bakıldığında çoğunlukla lise düzeyindeki ergenlerin flört ilişkilerindeki fiziksel ve psikolojik şiddeti hedef alan okul-temelli önleme programlarının geliştirildiği ve uygulandığı, diğer çalışmaların ise üniversite öğrencilerine ve cinsel flört şiddetine odaklandığ 1 görülmektedir (Cornelius ve Resseguie, 2007). Geliştirilen programların çoğu birincil önleme yaklaşımını benimsemekte ve flört şiddetinin henüz oluşmadan engellenmesini hedeflemektedir (WHO, 2010). Bu programların hemen hepsi, kadına yönelik şiddet konusundaki feminist yaklaşımların etkisiyle geleneksel toplumsal cinsiyet rolleri ve bunlara ilişkin kalıp yargıları değiştirmeye çabalamış; güç eşitsizliği, kontrolcü ilişki dinamikleri, flört şiddeti konularındaki bilgi ve farkındalığı artırmayı hedeflemiştir (Dobash ve Dobash, 1984; Shorey ve ark., 2008; Theriot, 2008). Bunun yanı sira, bu programlarda psikolojik kuramların etkisiyle sosyal ve ilişkisel becerilerin geliştirilmesi hedeflenmiş; çatışma çözme, öfke kontrolü, duygu düzenleme gibi konularda eğitici faaliyetlere yer verilmiştir (Meyer ve Stein, 2004; O’Leary, Woodin ve Fritz, 2006). Süresi, yoğunluğu, uygulama biçimi, faaliyetleri bakımından çeşitlilik gösterse de flört şiddetini önleme programlarının çeșitli kuramsal yaklaşımları bir araya getirerek bütünsel bir bakış açısı benimsediği söylenebilir.

Alan yazında en sık karşılaşılan programlardan biri lise öğrencilerine yönelik olarak birincil önleme hedefiyle geliştirilmiş Güvenli Flört (Safe Dates) programıdır. $\mathrm{Bu}$ program öğretmenler tarafindan uygulanan 10 oturumluk sınıf içi faaliyetleri, bir tiyatro oyununu ve bir poster yarışmasını içermektedir. Programın temel hedefleri flört şiddetine ve toplumsal cinsiyet rollerine ilişkin tutumları değiştirmek, çatışma çözme becerilerini geliştirmek ve flört şiddeti uygulayan veya buna maruz bırakılan gençlerin faydalanabileceği hizmet ve destekler konusunda bilgilendirme yapmaktır (Foshee ve ark., 1998, 2000, 2004, 2005). Gençlik ve İlişkiler Projesi (The Youth Relationships Project) ise benzer hedeflerle geliştirilmiş bir başka önleme programıdır. Bu programda 2 saat süren 18 oturum gerçekleştirilmekte, yetiştikleri aile içinde şiddete maruz bırakılmış gençlere odaklanarak canlandırma yapma, video izleme, sosyal değişim projesi tasarlama gibi farkındalık artırma ve beceri geliştirme temelli faaliyetler yürütülmektedir (Pittman ve ark., 2000; Wolfe ve ark., 1996). Bunların yanı sıra, çeşitli ülkelerde benzer hedeflerle geliştirilmiş ve uygulanmış programların olduğu bildirilmiştir (Antle, Sullivan, Dryden, Karam ve Barbee, 2011; Avery-Leaf, Cascardi, O'Leary ve Cano, 1997; Ball, Kerig ve Rosenbluth, 2009; Ball ve ark., 2012; Jaycox ve ark., 2006; 
Ntinapogias, Petroulaki ve Tsirigoti, 2011; Pearson, 2004; Taylor, Stein, Mumford ve Woods, 2013; Tsirigoti, Petroulaki ve Ntinapogias, 2011).

Sözü geçen flört şiddetini önleme programlar1nın çeşitli değişkenler üzerindeki etkileri araştırılmış, birincil önleme çalışmaları için destekleyici bulgular elde edilmiştir. Yapılan çalışmaların bazıları, flört şiddeti uygulama davranışına odaklanmış, programların bu davranışlar üzerindeki olumlu etkilerine işaret etmiştir. Örneğin, Foshee ve arkadaşları (1998, 2004, 2005) Güvenli Flört programına katılan öğrencilerin flört ilişkilerinde fiziksel, cinsel ve psikolojik şiddet uygulama davranışlarının azaldığını göstermiş, bu etkinin 4 yıla kadar korunabildiğini bildirmiştir. Bir başka çalışmada, Wolfe ve arkadaşları (2003, 2009) Gençlik ve İlişskiler Projesi'nin aile içi şiddete maruz bırakılmış ergenlerin flört ilişkilerinde şiddet uygulama davranışlarını azalttığını ve bu etkinin 4 yıla kadar korunduğunu saptamıştır. Başka araştırmalar da programların öz-bildirime dayalı şiddet uygulama ölçümleri üzerinde beklenen yönde bir etkisinin olduğuna işaret etmektedir (Ball ve ark., 2009, 2012).

Diğer çalışmalar, flört şiddeti önleme programlarının şiddet uygulama riskini artıran tutumlar ve bilgi düzeyi üzerindeki etkisini incelemiştir. Bulgular programların flört şiddetini kabullenici ve meşrulaştırıcı tutumları azalttığını (Antle ve ark., 2011; Avery-Leaf ve ark., 1997; Foshee ve ark., 1998, 2000, 2005; Krajewski, Rybarik, Dosch ve Gilmore, 1996; Kuffel ve Katz, 2002), geleneksel toplumsal cinsiyet rollerine ilişsin kabullenici tutumları zayıflattığını (Foshee ve ark., 1998, 2000; Schwartz, Magee, Griffin ve Dupuis, 2004; Schwartz, Griffin, Russel ve Frontaura-Duck, 2006) ve bu etkilerin 4 yıla kadar korunabildiğini (Foshee ve ark., 1998, 2000, 2005) göstermiştir. Buna ek olarak, bu tür programlara katılmanın flört şiddetiyle ilgili bilgi düzeyini artırdığ1 (MacGowan, 1997), fiziksel, cinsel ve psikolojik şiddetin işaretlerini tanıma becerisini geliştirdiği (Kuffel ve Katz, 2002) ve bu etkilerin 6 aya kadar korunabildiği (Krajewski ve ark., 1996; Lavoie, Vezina, Piche ve Boivin, 1995; Weisz ve Black, 2001) bildirilmiştir.

Ergen ve gençlerin flört ilişkilerindeki ilişkisel becerilerini desteklemek ve onların gelişim gösterebileceği bir ortam oluşturmak önleyici programların bir diğer hedefidir. $\mathrm{Bu}$ çerçevede yapılan araştırmalar bazı önleme programlarının iletişim becerilerinde artışı (Foshee ve ark., 1998, 2000), öfke kontrolü becerilerinde ve öfkeye ilişkin farkındalıkta artışı (Schwartz ve ark., 2004) ve şiddet içeren çatışma çözme yöntemlerinde azalmay1 (Ball ve ark., 2012) sağladığını bildirmiştir. Buna karşın, diğer çalışmalar programların çatışma çözme becerileri ve ilişkisel beceriler üzerindeki olumlu etkilerinin 2.5-4 yıllık izleme süreleri içinde korunamadığını göstermiştir
(Foshee ve ark., 2005; Wolfe ve ark., 2003). Bu bulgular programların kısa vadede ilişkisel beceriler üzerinde olumlu etkilerine işaret ederken bu etkilerin uzun vadede korunup korunamadığı sorusunu uyandırmaktadır.

Sözü geçen flört şiddeti önleme programlarının büyük çoğunluğu kız ve erkek öğrencilerin bir arada bulunduğu karma gruplara uygulanmakta (Foshee ve ark., 2004, 2005; Pittman ve ark., 2000; Wolfe ve ark., 1996), az sayıda çalışmada ise kız ve erkek öğrenciler programa ayrı gruplarda katılmaktadır (Ball ve ark., 2012). Alan yazına bakıldığında önleme programlarında cinsiyete özgü müdahalelerin gerekli olup olmadığının tartışıldığ1, karma grupların gruba aidiyet ve bağlılık, karşı cinsle iletişim, kız ve erkek öğrencilerin cinsiyetçi tutumlarını değiştirme olanağ dirildiği görülmüştür (Elias-Lambert, Black ve Sharma, 2010). Cinsiyetin program etkinliği üzerindeki etkisi s1nırlı sayıda araştırmada ele alınmıştır ve elde edilen bulgular tutarsızdır. Önceki araştırmalardan bazıları karma gruplarda uygulanan flört şiddetini önleme programlar1nın kız ve erkek öğrenciler üzerindeki etkisinde bir fark saptayamamıştır (Antle ve ark., 2011; Foshee ve ark., 1998, 2005). Buna karşın, diğer araştırmalar bu tür programların erkek öğrencilerin fiziksel şiddet uygulama davranışlarını azaltmada (Wolfe ve ark., 2009), kız öğrencilerin tutumlarını değiștirmede (Jaffe, Sudermann, Reitzel ve Killip, 1992) daha etkili olabildiğine işaret etmiştir. Araştırma bulgularındaki bu tutarsızlık, önleme programlarına katılan öğrencilerin yaşları, gelişim düzeyleri, flört şiddeti uygulama veya maruz bırakılma durumları, aile içi şiddet deneyimleri ve programların içeriğindeki çeşitlilikle açıklanabilir. $\mathrm{Bu}$ bağlamda programların etkinliğini artırmak için cinsiyetin ve diğer özelliklerle arasındaki etkileşimin araştırılmasının önemine vurgu yapılmıştır (Elias-Lambert, Black ve Sharma, 2010).

Yukarıda özetlenen bulgular 1şı̆̆ında, önleyici yaklaşımların gençlerin flört ilişkilerinde şiddetin oluşmasını engellemede ve kadına yönelik şiddeti azaltmada umut vadeden bir mücadele yöntemi olabileceği düşünülmektedir. $\mathrm{Bu}$ tür müdahaleler gençler arasında eşitlikçi değerlerin güçlenmesine, güvenli ilişkiler kurulmasına ve gençlerin özellikle de genç kadınların pek çok olumsuz deneyimden korunmasına yardımcı olabilir. Ergenlik ve erken yetişkinlik dönemlerinde kurulan flört ilişkilerinin hayatın sonraki aşamalarında karakter gelişimi, sosyal gelişim, psikolojik ve sosyal işlevselliği etkilediği bilindiğinden (Collins, Welsh ve Furman, 2009) bu yaş grubunu hedef alan önleyici çalışmaların artması büyük önem taşımaktadır.

\section{Türkiye'de Flört Şiddeti ve Önleme Çalışmaları}

Türkiye'de üniversite öğrencileriyle yapılan çalışmalar flört şiddetinin yaygın ve ciddi bir sorun olduğuna 
işaret etmektedir. Örneğin, 1 y1l veya daha kısa süreyle flört ilişkisi olmuş 206 kadının katıldığı bir araştırmada, kadınların \% 31.6'sının cinsel, \% 32.5'inin fiziksel ve \% 67.5 'inin psikolojik şiddet deneyimi olduğu ve şiddetin farklı biçimlerinin bir arada görülme durumunun yaygın olduğu bulunmuştur (Toplu-Demirtaş, Hatipoğlu-Sümer ve White, 2013). Ülkemizde üniversite öğrencileriyle yapılan diğer araştırmalar gençlerin flört ilişkilerinde k1sıtlayıcı ve şiddet içeren davranışları normalleştirdiğini (Aslan ve ark., 2008; Çimen, 2018), cinsiyetçi tutumların etkisiyle kadına yönelik şiddeti kabullenici tutumlar sergileyebildiğini (Hüsnü ve Mertan, 2017; Sakall1-Uğurlu ve Ulu, 2003) ve cinsellik deneyimlerinin toplumsal cinsiyet rolleri çerçevesinde şekillendiğini (Bolak-Boratav ve Çavdar, 2012) göstermiştir. Son yıllarda ülkemizde sevindirici biçimde artan tez çalışmaları da flört şiddetinin toplumsal cinsiyet normlarıyla ve şiddete yönelik kabullenici tutumlarla ilişkisini açıklamaktadır (Cinal, 2018; Çimen, 2018; Y1ldırım, 2016).

Gençlerin içinde yetiştikleri sosyo-kültürel ortam ve toplumsal yapı düşünüldüğünde, flört şiddetinin yaygın olması ve cinsiyetçi inançlar ile şiddete ilişkin kabullenici tutumların benimsenmesi şaşırtıcı değildir. Önceki çalışmalar, Türkiye'deki kadın-erkek ilişkisi normlarının ataerkil hiyerarşi ile tanımlandığını (Fişek, 1995; Sunar ve Fișek, 2005), namus kültürünün erkeğin kadın üzerindeki kontrolünü ve kadına yönelik şiddeti meşrulaştırd1ğını (Ceylan, Doğulu ve Akbaş, 2016; Sakall1-Uğurlu ve Akbaş, 2013) ve cinsiyetçi inançların yaygın olduğunu (Glick ve ark., 2004) göstermiştir. Üniversite öğrencileri, her ne kadar daha liberal değerler benimseme eğilimi gösterseler de, yaşadıkları toplumun değer yargılarından etkilenebilir ve flört şiddetine yönelik beklenti ve tutumları bu çerçevede şekillenebilir. Bu nedenle, gençler için ataerkil ve cinsiyetçi yarg1 ve normların sorgulanabileceği, eşitlikçi tutum ve davranışların destekleneceği sosyal ortamlar yaratmak önleme çalışmalarının ilk adımlarından biri olmalıdir.

Türkiye, 2011 yılında Kadına Yönelik Şiddetin ve Aile İçi Şiddetin Önlenmesi ve Bunlarla Mücadeleye İlişkin Avrupa Konseyi Sözleşmesi'ni (İstanbul Sözleşmesi) imzalamıştır. Bu sözleşmenin 13. maddesi gereğince ev içinde, yakın ilişkilerde ve flört ilişkilerinde şiddetin engellenmesi ve bu konuda farkındalığın arttırılması için önleyici çalışmaların yürütülmesi gerekmektedir. Bazı kadın örgütleri ve sivil toplum kuruluşları flört şiddeti konusunda bilgilendirici ve farkındalık artırıcı çalışmalar yürütmekte, araştırmacılar flört şiddeti konusunda farkındalığın artması ve eşitlikçi değerlerin yaygınlaşması konusunda müdahale çalışmalarının önemine vurgu yapmaktadır (Aslan ve ark., 2008; Kılınçer ve Tuzgöl-Dost, 2014; Selçuk ve ark., 2018; Yıldırım, 2016). Alan yazına bakıldığında, bu konuda yapılan tek çalışmanın Özdere ve Kürtül (2017) tarafindan yürütülen ve 1 saatlik toplantılardan oluşan bir flört şiddeti eğitimi olduğu görülmektedir. Bu önemli bir adım niteliğinde olmakla birlikte, daha kapsamlı ve etkisi sınanmış bir önleme programına ihtiyaç olduğu düşünülmektedir. $\mathrm{Bu}$ çalışma üniversite öğrencilerine yönelik grup-temelli bir flört şiddeti önleme programı geliştirerek ve programın etki değerlendirmesini yaparak ulusal alan yazındaki bu boşluğu doldurmayı hedeflemektedir. Bu çalışmada programın bir dizi davranış ve tutum üzerindeki etkisi araştırılmış, şu hipotezler sınanmıştır: a) Son-testte programa katılan öğrencilerin yapıcı çatışma çözme davranışları artacak, programa katılmayan kontrol grubunun davranışlarında ise ön-testten son-teste bir değişim olmayacaktır (Zaman ve Grup arasında istatistiksel olarak anlamlı bir etkileşim bulunacaktır). b) Son-testte programa katılan ögrencilerin cinsiyetçi tutumları azalacak, kontrol grubunun tutumlarında ise ön-testten son-teste bir değişim olmayacaktır (Zaman ve Grup arasında istatistiksel olarak anlamlı bir etkileşim bulunacaktır). c) Son-testte programa katılan öğrencilerin flört şiddetine yönelik kabullenici tutumları azalacak, kontrol grubunun tutumlarında ise ön-testten son-teste bir değişim olmayacaktır (Zaman ve Grup arasında istatistiksel olarak anlamlı bir etkileşim bulunacaktır). Buna ek olarak, programın kadın ve erkek öğrenciler üzerindeki etkisinde bir fark olup olmadığı araştırılmış, her bir hipotez için cinsiyetin etkisi incelenmiştir. Bu konuda alan yazındaki bulgular tutarsız olduğundan herhangi bir hipotez kurulamamıştır.

\section{Yöntem}

\section{Program Geliştirme}

Çalışmada öncelikle üniversite öğrencilerine yönelik grup-temelli uygulanabilecek bir flört şiddetini önleme programı oluşturulmuştur. Programın amacı öğrencileri flört şiddeti konusunda bilgilendirmek, flört ilişkilerinde karşılaştıkları şiddet içeren ve kontrolcü davranışları tanıma ve başa çıkma becerilerini desteklemek, daha güvenli ve eşitlikçi ilişkiler kurmaları yönünde rehberlik etmek ve yapıcı çatışma çözme becerilerini geliştirmektir. Program, feminist klinik yaklaşımların ve araştırmaların etkisiyle farkındalık artırma, psiko-eğitim ve beceri geliştirme unsurlarından oluşmuştur (Aronson ve Buchholz, 2001; Enns, 1992; Goldner, 1998, 1999, 2004; Knudson-Martin, 2013; Lyness ve Lyness, 2007). Programın taslağ1 oluşturulmadan önce üniversite öğrencileriyle 19 ön görüşme gerçekleştirilmiş ve flört şiddetine ilişkin bilgi düzeyleri, flört ilişkilerinde yaşanan sorunlar, flört şiddetiyle karşılaştıkları durumlar ve çözüm önerileri araştırılmıştır. Bu görüşmelerle programın üniversite öğrencilerinin flört şiddeti konusundaki bilgi 
Tablo 1. Program Geliştirme Sürecinde Yapılan Ön Görüşmelerden Çıkan Temalar ve Açıklamaları

\begin{tabular}{|c|c|c|}
\hline Soru & Temalar & Açıklama \\
\hline \multirow{4}{*}{$\begin{array}{l}\text { Flört ilişkilerinde sorun } \\
\text { yaratan konular/durumlar }\end{array}$} & Kıskançlık & $\begin{array}{l}\text { Arkadaşlara ayrılan zaman (çoğunlukla karşı cins), sosyal } \\
\text { medya kullanımı ve kurulan arkadaşlıklar, giyim tarzı ve dış } \\
\text { görünüş }\end{array}$ \\
\hline & Kontrolcü davranışlar & $\begin{array}{l}\text { Sevgilinin seçimlerini kısıtlama, sevgilinin kimlerle olduğunu } \\
\text { ve nereye gittiğini sürekli kontrol etme }\end{array}$ \\
\hline & Farkl111klar & $\begin{array}{l}\text { Beklenti, düşünce ve inançların birbirinden farklı olması, } \\
\text { sevgiliyi ikna etme ve değiştirme çabası }\end{array}$ \\
\hline & İletişimsizlik & $\begin{array}{l}\text { Kendini ifade etmede zorluk, sevgiliye empati göstermede } \\
\text { zorluk }\end{array}$ \\
\hline \multirow{4}{*}{$\begin{array}{l}\text { Flört şiddetine ilişkin bilgi } \\
\text { düzeyi }\end{array}$} & Fiziksel şiddet & $\begin{array}{l}\text { Erkeklerin uyguladığı fiziksel şiddeti vurgulama, toplumsal } \\
\text { cinsiyet normlarına ve sosyal ögrenme süreçlerine vurgu } \\
\text { yapma }\end{array}$ \\
\hline & Psikolojik şiddet & $\begin{array}{l}\text { Kadın ve erkeklerin sevgiliyi kontrol etme ve sevgiliyle güç } \\
\text { mücadelesine girme davranışları, psikolojik şiddetin sevgi ve } \\
\text { ilgi göstergesi olarak anlaşılması }\end{array}$ \\
\hline & Cinsel şiddet & $\begin{array}{l}\text { Cinsellik konusunda toplumsal normlara vurgu yapma, } \\
\text { erkekler üzerinde cinsellikle ilgili baskı olması }\end{array}$ \\
\hline & Dijital şiddet & $\begin{array}{l}\text { Dijital araçlarla şiddet uygulamanın kolay olması, dijital } \\
\text { araçların ulaşılabilirliği, dijital şiddetin kıskançlık ve kontrolle } \\
\text { ilişkisi }\end{array}$ \\
\hline \multirow{3}{*}{$\begin{array}{l}\text { Flört şiddetini önlemek için } \\
\text { çözüm önerileri }\end{array}$} & $\begin{array}{l}\text { Toplumsal cinsiyet normlarının } \\
\text { sorgulanması }\end{array}$ & $\begin{array}{l}\text { Kadınlık ve erkeklik tanımlarının sorgulanması, toplumsal } \\
\text { cinsiyet rollerinin eleştirilmesi ve bu rollerin etkisiyle oluşan } \\
\text { ilişkisel beklentilerin değişmesi }\end{array}$ \\
\hline & Yakınlığın yeniden tanımlanması & $\begin{array}{l}\text { Yakın ilişkilerde farklılıkların kabul edilmesi, bireyselliğe } \\
\text { saygı duyulması }\end{array}$ \\
\hline & $\begin{array}{l}\text { İletişim kurmanın yollarının } \\
\text { öğrenilmesi }\end{array}$ & $\begin{array}{l}\text { Sözlü iletişim yollarının öğrenilmesi, sevgiliyi dinleme } \\
\text { becerisinin geliştirilmesi }\end{array}$ \\
\hline
\end{tabular}

düzeyine uygun olması, flört ilişkilerindeki deneyimlerine ve sorunlarına hitap etmesi ve program oluşturma sürecine aktif katılımlarının sağlanması hedeflenmiştir. $\mathrm{Bu}$ ön görüşmelerin bulguları Tablo 1'de sunulmuştur. Ön görüşme sonuçlarına göre, görüşülen öğrencilerin flört şiddeti konusunda farkındalığının ve bilgi düzeyinin görece yüksek olduğu ve toplumsal cinsiyet ve güç eşitliği, bireysellik ve kişisel sınırlar, yakınlık kurma ve duygusal iletişim temalarının öne çıktığı görülmüştür.

$\mathrm{Bu}$ görüşmelere dayanarak oturumlarda ele alınacak temalar belirlendikten sonra bir alan yazın taraması yapılmış; flört şiddetini önleme, toplumsal cinsiyet eşitliği ve psiko-eğitim grupları konularında sivil toplum örgütleri ve akademisyenler tarafından yayınlanan ve uygulanan programlar incelenmiştir (Koberlein ve ark., 2010; Ntinapogias ve ark., 2011; Tsirigoti ve ark., 2011; Wolfe ve ark., 1996). Buna ek olarak, grup-temelli çalışmalar ve psiko-eğitim grupları konularındaki çeşitli kitap ve materyaller taranmış (Belmont, 2006; Brown, 2013; Elliott, 1994) ve ergen ve gençlere yönelik hazır- lanmış bilgilendirici internet siteleri gözden geçirilmiştir (loveisrespect.org, 40tilkiblog.wordpress.com, morcati. org). Daha sonra, Nation ve arkadaşlarının (2003) etkili önleme programlarının özellikleriyle ilgili tavsiyelerine uygun olarak didaktik öğretme yöntemlerini en az düzeyde kullanan, grup üyeleri arasındaki iletişimi ve fikir alışverişini destekleyecek, çizim ve bedensel hareketler gibi farklı ifade yöntemlerini içeren ve çalışmanın kuramsal yaklaşımıyla uyumlu bir dizi faaliyet geliştirilmiştir. $\mathrm{Bu}$ faaliyetler oturum temaları altında gruplandırılarak 8 oturumluk bir flört şiddeti önleme programı oluşturulmuştur. Geliştirilen program alan yazındaki diğer önleme programlarıyla benzer hedeflere sahip olmasına rağmen, üniversite öğrencilerine yönelik olarak hazırlanması, feminist klinik yaklaşımları kuramsal bir çerçeve olarak alması, görece yeni bir şiddet biçimi olan dijital flört şiddetini işlemesi ve ön görüşmelerde sıklıkla vurgulanan kıskançlık temasına odaklanması bakımından diğer programlardan ayrılmaktadır. Programın bir kopyası yazardan edinilebilir. 


\section{Pilot Çalıșma}

İlk olarak, çalışmanın yürütüldüğü üniversitenin etik kurulundan izin alınmıştır. Daha sonra hazırlanan programın içerik ve zamanlama bakımından üniversite öğrencileri için uygun olup olmadığını görmek ve programın etkilerini gözlemlemek için bir pilot çalışma yürütülmüştür. Pilot çalışmada program İstanbul'da bir devlet üniversitesinde okumakta olan 2 öğrenci grubuna uygulanmış, program tamamlandiktan sonra katılımcilarla bireysel ve yarı yapılandırılmış görüşmeler yapılarak geri bildirimleri ve önerileri alınmıştır. İlk pilot gruba yaşları 21-26 arasında değişen 15 kadın ve 3 erkek öğrenci katılmış, ikinci pilot gruba yaşları 19-20 arasında olan 5 kadın ve 4 erkek öğrenci katılmıştır. Öğrencilere katılımları karşılığında kayıtlı oldukları psikoloji derslerinden ek puan verilmiştir. Pilot çalışma boyunca yapılan gözlemler ve katılımcıların verdiği geri bildirimler 1şı̆̆ında programda şu değişiklikler yapılmıştır: 1) Grup üyelerinin gözlem ve deneyimlerini konuşmak ve her üyeye eşit oranda zaman ayırabilmek için oturumlarda yapılan aktivite sayısı azaltılmış ve üye sayısı 8-11 olarak sınırlanmıștır. 2) Kişisel deneyimler üzerine düşünmeyi ve bağlantı kurmayı kolaylaştırmak için canlandırma yönergeleri değiştirilmiş, canlandırmalarda kişisel deneyimlere odaklanılmıştır. Örneğin, ikinci oturumda katılımc1lara bir senaryo verilmiş ve bu senaryodaki durumda nasıl hissedeceklerini ve davranacaklar1nı canlandırmaları istenmiştir. Bu durumlardan biri sevgilinin kendi arkadaşlarına çok vakit ayırdığını düşünmek, bir diğeri sevgilinin ara sıra eski sevgilisiyle telefonda konuşmasıdır. Kişisel sınırlar konusunun ele alındığı beşinci oturumda katılımcıların sevgilisine "hayır" demek istediği durum örnekleri verilmiș ve bu durumda nasıl hayır diyeceklerini canlandırmaları istenmiştir. Bu durumlardan biri sevgilinin e-posta veya sosyal medya hesaplarının şifresini istemesi, bir diğeri sevgilinin eski bir arkadaşınla görüşmeyi kesmeni istemesidir. Bu canlandırmalardan sonra katılımcılar duygu ve davranışlarını tüm grupla paylaşmış ve tepkileri güvenlik ve eşitlik bağlamında grup içinde tartışılmıştır. 3) Programın günlük hayat üzerindeki etkisini artırmak ve katılımcıların kendi duygu ve davranışlarıyla ilgili farkındalıklarını desteklemek için her oturumun konusuna ilişkin haftalık ödevler eklenmiştir. Örneğin, öfke duygusunun ele alındığ i ikinci oturumda katılımcılardan hafta içinde kendi duygularını gözlemlemesi, onlarda öfke uyandıran durumları saptaması ve öfkelendiklerinde kendi duygularını nasıl ifade ettiklerini düşünmeleri istenmiştir. Güç ve kontrol konusunun ele alındığı dördüncü oturumdan sonra katılımcıların güç eşitliği ve eşitsizliği bakımından çevrelerinde gözlemledikleri ilişkileri değerlendirmesi ve kendi flört ilişkilerinde nasıl bir ilişkisel rol üstlendiklerini gözlemlemesi istenmiştir. Bu gözlem ve farkındalık ödevleri, sonraki hafta oturumun başında grup içinde paylaşılmış ve tartışılmıştır. 4) Flört şiddeti konu- sunda bilgilendirme yapmak için kısa broşürler hazırlanmış ve her oturum sonunda bu broşürler grupta dağıtılmıştır. Bu değişiklikler sonucunda program son haline getirilmiştir. Programın asıl çalışmada uygulanan son halinin konuları, hedefleri ve faaliyetleri Tablo 2'de sunulmuştur.

\section{Asıl Çalışma}

\section{İșlem}

Asıl çalışma İstanbul'da pilot çalışmanın yürütüldüğü devlet üniversitesinde okuyan öğrencilerle gerçekleştirilmiştir. Asıl çalışmanın örneklemini oluşturmak için bu üniversitede Psikolojiye Giriş dersini alan öğrencilere bir davet e-postası gönderilmiş, bu e-postada programla ilgili kısa bir bilgi ve başvuru için araştırmacının iletişim bilgileri verilmiştir. Programa başvuruda bulunan öğrenciler arasından deney ve kontrol gruplarına seçkisiz atama yapılması planlanmış ancak gerçekleştirilememiştir. Programa başvuruda bulanan öğrenci sayısında grupların zamanlaması sırasında beklenenden daha fazla kayıp yaşanmıştır ( $\%$ 44) ve program uygulamasını bir akademik dönem içinde tamamlama gerekliliği nedeniyle yeni başvuru alınamamıştır. Kalan 65 öğrencinin sonraki aşamalarda çalışmadan ayrılma riski dikkate alınarak bu öğrencilerin tamamının deney grubuna dahil edilmesine karar verilmiş ve öğrenciler şu ölçütlere göre 4 gruba atanmıştır: a) Katılımcıların yaşları 18-22 arasında olmal1, b) Her bir grupta kadın ve erkek katılımcıların sayısı mümkün olduğunca eşit olmalı, c) Her bir gruptaki katılımc1lar mümkün olduğunca farklı bölümlerde okumalı, d) Her bir grupta 8-11 katılımeı olmalı. Daha sonra bu katılımcilar bir bilgilendirme toplantısına davet edilmiş, bu toplantıda programın içeriği, süreci ve haftalık konular açıklanmıştır. Bu bilgilendirme sonrasında 44 öğrenci (27 kadın, 17 erkek) programa katılmayı kabul etmiş ve ön-test ölçümlerini tamamlamıştır.

Deney grubu oluşturulduktan sonra 8 oturumluk flört şiddetini önleme programı katılımcılara uygulanmıştır. Oluşturulan 4 grubun oturumları birbirine paralel olacak şekilde yürütülmüş, her bir gruba aynı hafta aynı oturum uygulanmıştır. Program klinik psikoloji doktora eğitimi sürmekte olan yazar ve klinik psikoloji yüksek lisansına devam eden iki yardımcı grup lideri tarafindan uygulanmıştır. Program 1.5-2 saat süren haftalık oturumlar halinde yürütülmüş, sekizinci oturumun sonunda sontest ölçümleri yapılmıştır. Son-test ölçümlerinden önce 3 kadın katılımcı çeşitli nedenlerle programdan ayrılmıştır. Programdan sonra katılımcıların programla ilgili geri bildirimlerini ve önerilerini öğrenmek için her katılımcıyla bireysel ve yarı yapılandırılmış görüşmeler yapılmıştır.

Kontrol grubunun oluşturulması için Psikolojiye Giriş dersini alan öğrencilere yönelik bir ilan hazırlanmış ve psikoloji bölümündeki deney panosuna asılmış- 
Tablo 2. Geliştirilen Flört Şiddeti Önleme Programının Oturum Konuları, Hedefleri ve Aktiveleri

\begin{tabular}{|c|c|c|c|}
\hline Oturum & Konu & Hedefler & Aktiviteler \\
\hline 1 & Tanışma & $\begin{array}{ll}\text { - } & \text { Grup üyelerinin birbiriyle ve grup liderleriyle tanışmasını sağlamak } \\
\text { - } & \text { Grup içi iletişimi desteklemek } \\
\text { - } & \text { Güvenli ve zedeleyici/şiddet içeren ilişkiler konusuna giriş yapmak } \\
& \text { Gruelerini flört ilişkilerindeki kişisel haklar konusunda bilgilendirmek }\end{array}$ & $\begin{array}{l}\text { Tanışma oyunları, grup } \\
\text { tartışmaları }\end{array}$ \\
\hline 2 & $\begin{array}{l}\text { Psikolojik } \\
\text { Şiddet }\end{array}$ & $\begin{array}{l}\text { - Grup üyelerinin flört ilişkilerinde öfkeyi ifade etme biçimleri üzerine } \\
\text { düşünmesini sağlamak } \\
\text { - } \quad \text { Öfkeyi ifade etmenin zedeleyici/şiddet içeren yollarını tanımlamak } \\
\text { - Grup üyelerini sözlü şiddet konusunda bilgilendirmek }\end{array}$ & $\begin{array}{l}\text { Grup tartışmaları, } \\
\text { canlandırmalar }\end{array}$ \\
\hline 3 & $\begin{array}{l}\text { Psikolojik } \\
\text { Şiddet }\end{array}$ & $\begin{array}{ll}\text { - } & \text { Öfkeyi ifade etmenin güvenli yollarını tanımlamak, bunları kullanmak } \\
\text { için pratik yapmak } \\
\text { - Öfkeyi kontrol etmenin yollarını tanımlamak, bunları kullanmak için } \\
\text { pratik yapmak } \\
\text { - } \quad \text { Grup üyelerini psikolojik şiddet konusunda bilgilendirmek }\end{array}$ & $\begin{array}{l}\text { Grup tartışmaları, } \\
\text { canlandırmalar }\end{array}$ \\
\hline 4 & $\begin{array}{l}\text { Güç ve } \\
\text { Kontrol }\end{array}$ & $\begin{array}{l}\text { - } \quad \text { Flört ilişkilerinde güç eşitliği/eşitsizliğinin işaretlerini tanımak } \\
\text { - } \quad \text { Grup üyelerini güç ve kontrol davranışları konusunda bilgilendirmek }\end{array}$ & $\begin{array}{l}\text { Video tartışması, } \\
\text { heykel yapma, grup } \\
\text { tartışmaları }\end{array}$ \\
\hline 5 & Fiziksel Şiddet & $\begin{array}{ll}\text { - } & \text { Flört ilişkilerinde kişisel sınırları belirlemek } \\
\text { - } & \text { Flört ilişiklerinde kişisel sınırları korumak için pratik yapmak } \\
\text { - } & \text { Grup üyelerini fiziksel şiddet ve şiddet döngüsü konusunda bilgilendirmek }\end{array}$ & $\begin{array}{l}\text { Oyun, görselleştirme ve } \\
\text { çizim, canlandırmalar }\end{array}$ \\
\hline 6 & Dijital Şiddet & $\begin{array}{ll}\text { - } & \text { Flört ilişkilerinde kıskançlık ve kontrol isteğini anlamak } \\
\text { - } & \text { Flört ilişkilerinde kıskançlıkla baş etme yöntemleri aramak, kıskançlığ1 } \\
\text { güvenli bir şekilde ifade etmek için pratik yapmak } \\
\text { - } \quad \text { Grup üyelerini dijital şiddet konusunda bilgilendirmek }\end{array}$ & $\begin{array}{l}\text { Görselleştirme ve } \\
\text { çizim, canlandırmalar }\end{array}$ \\
\hline 7 & Cinsel Şiddet & $\begin{array}{ll}\text { - } & \text { Cinsel sınırlar ve rıza kavramını tanımlamak } \\
\text { - } & \text { Rıza almak/vermek için atılabilecek adımları belirlemek, pratik yapmak } \\
\text { - } & \text { Grup üyelerini cinsel güvenlik ve şiddet konusunda bilgilendirmek }\end{array}$ & $\begin{array}{l}\text { Video tartışması, } \\
\text { senaryo tartışması, } \\
\text { canlandırmalar }\end{array}$ \\
\hline 8 & $\begin{array}{l}\text { Değerlendirme } \\
\text { ve Veda }\end{array}$ & $\begin{array}{ll}\text { - } & \text { Grup sürecini sonlandırmak } \\
& \text { Grup sürecine ilişkin genel bir değerlendirme yapmak }\end{array}$ & $\begin{array}{l}\text { Grup yapbozu, heykel } \\
\text { yapma, grup tartışması }\end{array}$ \\
\hline
\end{tabular}

tır. Bir hafta içerisinde 51 öğrenci (26 kadın, 25 erkek) ilana yanıt vermiş, ön-test ölçümlerini tamamlamıştır. Kontrol grubundaki katılımc1lara herhangi bir müdahale yapılmamıştır. Kontrol grubu 2-2.5 ay arayla ön-test ve son-test ölçümlerine davet edilmiş, bu ölçümlerin zamanlaması deney grubuyla paralel olacak şekilde planlanmıştır. Ön-test ölçümünde, çalışmanın iki aşamasının olduğu açıklanmış, bilgilendirilmiş onam formları ve ölçekler dağıtılmış, katılımcılara ulaşılabilecek e-posta adresleri toplanmıştır. Son-test ölçümlerinin zamanı geldiğinde katılımcılara e-posta yoluyla bir davet gönderilmiş ve ölçümler tamamlanmıştır. Son-test ölçümlerinden önce bir kadın, bir erkek katılımcı çalışmadan ayrılmıştır. Ön-test ve son-test ölçümleri 20-30 dakika sürmüş, yazar ve bir öğrenci asistan tarafından yürütülmüştür.

Bu çalışma birincil önleme niteliğinde olduğundan deney ve kontrol gruplarına katılmak isteyen öğrenciler önceki flört veya şiddet deneyimlerine bakılmaksızın araştırmaya kabul edilmiştir. Bazı katılımcıların o sırada veya araştırma öncesinde flört ilişkisi olmayabileceği düşünülmüş ve ölçeklerin yanıtlanmasını kolaylaştırmak için katılımcılardan varsa o sıradaki flört ilişkilerini, yoksa geçmişteki flört ilişkilerini, hiç flört ilişkisi olmadıysa yakın arkadaşlık ilişkilerini düşünerek yanıt vermesi istenmiştir. Önceki flört şiddetini önleme çalışmalarında da yaşıtlarla kurulan ilişkilerdeki değişimin bir sonuç değişkeni olarak araştırıldığı görülmektedir (Wolfe ve ark., 2009). Son-test ölçümlerinde katılımc1lardan son 2 ay içindeki deneyimlerini düşünerek yanıt vermesi istenmiş, bu sayede programın kısa süreli etkilerinin saptanması hedeflenmiştir.

Deney ve kontrol grubundaki öğrenciler, çalışmaya katılımları karşılığında kayıtlı oldukları Psikolojiye Giriş dersi için ek puan kazanmıştır.

\section{Örneklem}

Son örneklemde deney grubunda programı tamamlamış 41 katılımcı (24 kadın, 17 erkek), kontrol grubunda ise 49 katılımcı (25 kadın, 24 erkek) bulunmaktadır. Katılımcıların yaşları 18-22 arasında değişmektedir. 


\section{Veri Toplama Araçları}

Çatışmaların Çözümü̈ne Yaklaşım Ölçeği (ÇÇYÇ). Straus ve ekibi tarafından geliştirilen (Straus 1979, 2004; Straus, Hamby, Boney-McCoy ve Sugarman, 1996) ve Aba (Aba, 2008, Aba ve Kulakaç, 2016) tarafından Türkçeye uyarlanan ölçek yakın ilişkilerde partnere şiddet uygulama ve partner şiddetine maruz kalma sıklığını ölçmektedir. Ölçek, farklı şiddet türlerine ilişkin davranışsal betimlemeleri içeren 78 maddeden oluşmakta; uzlaşma, fiziksel şiddet, psikolojik şiddet, cinsel şiddet ve yaralanma alt ölçeklerini içermektedir. Ölçekte katılımcılardan her bir maddede açıklanan davranışları son bir yıl içinde veya daha önce gösterip göstermediklerini ve bu davranışa maruz kalıp kalmadıklarını 8 puan üzerinden değerlendirmesi istenir $(0=$ Hiç, 1 $=$ Bir kez, $7=$ Son bir yıldan daha önce). Bu çalışmada ÇÇYÇ'nin üç alt ölçeği, son bir yıl içinde katılımcıların flört ilişkilerinde gösterdiği veya maruz bırakıldığı fiziksel, psikolojik ve cinsel şiddet davranışlarını ölçmek ve durumlarını saptamak amacıyla yalnızca ön-test ölçümünde kullanılmıștır. Bu alt ölçeklerin Cronbach alfa iç tutarlılık katsayıları sırasıyla $.78, .82$ ve .60 olarak bulunmuştur. $\mathrm{Bu}$ örneklemde fiziksel ve cinsel şiddet uygulama ve maruz birakılma sıklığı çok düşük olduğundan, farklı şiddet türlerine verilen yanıtlar toplanmış, biri şiddet uygulama, diğeri şiddete maruz kalma olmak üzere iki toplam puan oluşturulmuştur. Yüksek puanlar, son bir yıl içinde flört şiddeti uygulama ve şiddete maruz kalmanın daha sık olduğunu gösterir.

İkili İlişskilerde Çatışma Çözme Tepkileri Ölçeği (ïÇCTÖ). Rusbult ve arkadaşları tarafından geliștirilen (Rusbult ve Zembrodt, 1983; Rusbult, Verette, Whitney, Slovik ve Lipkus, 1991; Kilpatrick, Bissonnette ve Rusbult, 2002) ve Taluy (2013) tarafindan Türkçeye uyarlanan İ̈ÇÇTÖ yakın ilişkilerde sorunlara verilen tepkileri ölçmektedir. Ölçek 16 maddeden ve aktiflik-pasiflik ile yapıcılık-yıkıcılık boyutlarında farklılaşan 4 alt ölçekten oluşmaktadır. Bu alt ölçekler çıkış, yokmuş gibi davranma, konuşma ve bağlılık olarak tanımlanmıştır. Çıkış bir çatı̧̧ma durumunda partneri ayrilıkla tehdit etme veya terk etme tepkilerini içeren aktif ve yıkıcı davranışlar, yokmuş gibi davranma ise çatı̧̧mayı görmezden gelme veya konudan kaçınma tepkilerini içeren pasif ve yıkıcı davranışlardır. Konuşma çatışma yaratan sorunun çözümü için destek arama veya kendini ifade etme gibi aktif ve yapıcı davranışları içerirken, bağlılık iyimser bir şekilde sorunun çözülmesini umut etmek gibi pasif ve yapıcı tepkileri tanımlar. Ölçek maddeleri ilişkideki sorunlar karşısında verilebilecek bu tür tepkilerin betimlemelerini içerir ve katılımcılardan bu davranışları hangi sıklıkta sergilediklerini 9 puan üzerinden değerlendirmesi istenir $(1=$ Hiçbir zaman, $9=$ Her zaman $)$. Bu çalış̧mada İICCÇTÖ bir tartışma durumunda kullanılan yapıcı çatışma çözme becerisinde programa bağlı bir gelişme olup olmadığını araştırmak amacıyla ön-test ve son-test ölçümlerinde kullanılmıştır. Yıkıc1lık boyutuna verilen puanlar ters kodlanmış, tüm maddelere verilen puanların ortalaması alınarak genel bir yapıcı çatışma çözme puanı elde edilmiştir. Ölçeğin Cronbach alfa iç tutarlılık katsayısı ön-test ve son-test için sırasıyla .77 ve .78 olarak bulunmuştur. Yüksek puanlar, bir sorun karşısında yapıcı çatışma çözme eğilimine işaret eder.

Çelişik Duygulu Cinsiyetçilik Ölçeği (ÇDCÖ). Glick ve arkadaşları (Glick ve Fiske, 1996; Glick ve ark., 2000) tarafindan geliştirilen ve Sakall1-Uğurlu (2002) tarafindan Türkçeye uyarlanan ÇDCÖ cinsiyetçi tutumları ölçmektedir. Ölçek kadınlara karşı olumsuz ve düşmanca tutumları içeren düşmanca cinsiyetçilik ile kadınları korunmaya muhtaç, naif, kırılgan olarak tanımlayan korumacı cinsiyetçilik alt ölçeklerinden oluşmaktadır. Ölçeğin 6 puan üzerinden değerlendirilen 22 maddesi bulunmaktadır $(1=$ Kesinlikle katılmıorum, $6=$ Kesinlikle katılıyorum). Bu çalışmada, ÇDCÖ çelişik duygulu cinsiyetçi tutumlarda programdan sonra bir azalma olup olmadığını araştırmak amacıyla ön-test ve son-test ölçümlerinde kullanılmıştır. İki alt ölçek için ilgili maddelere verilen puanların ortalaması alınarak düşmanca ve korumacı cinsiyetçilik tutumu puanları hesaplanmıştır. Alt ölçeklerin Cronbach alfa iç tutarlılık katsayıları öntest ve son-test için sırasıyla .93 ve .89 olarak bulunmuştur. Yüksek puanlar daha cinsiyetçi tutumlara işaret eder.

Flört Şiddetine Yönelik Tutum Ölçekleri (FŞTÖ). Price ve arkadaşları (1999) tarafindan geliştirilen ve Yumuşak tarafindan (Yumuşak, 2013; Yumuşak ve Şahin, 2014) Türkçeye uyarlanan FŞTÖ flört şiddetine yönelik tutumları ölçmektedir. FŞTÖ, heteroseksüel ilişkilerde kadın ve erkeklerin uyguladığ 1 psikolojik, fiziksel ve cinsel şiddete yönelik tutumları ölçen 6 alt ölçekten oluşmaktadır. Ölçek partneri kontrol etme, kıskançlık nedeniyle partneri kısıtlama, partnere bağırma gibi davranışları içeren bir dizi maddeden oluşmakta, katılımcılardan bu tür davranışları ne ölçüde kabul edilebilir buldukların1 5 puan üzerinden değerlendirmesini istemektedir (1 $=$ Kesinlikle katılmıyorum, $5=$ Kesinlikle katılıyorum). $\mathrm{Bu}$ çalışma kapsamında, FŞTÖ flört şiddetine yönelik kabullenici tutumlarda programdan sonra bir azalma olup olmadığını araştırmak amaciyla ön-test ve sontest ölçümlerinde kullanılmıştır. Bu amaçla, FŞTÖ'nün flört ilişkilerinde erkeklerin uyguladığı fiziksel şiddete yönelik tutum alt ölçeği (FŞTÖ-Fiziksel-E), kadınların uyguladığı fiziksel şiddete yönelik tutum alt ölçeği (FŞTÖ-Fiziksel-K), erkeklerin uyguladığı psikolojik şiddete yönelik tutum alt ölçeği (FŞTÖ-Psikolojik-E), kadınların uyguladığı psikolojik şiddete yönelik tutum alt ölçeği (FŞTÖ-Psikolojik-K) kullanılmıştır. İlgili maddelere verilen puanların ortalaması alınarak dört ayrı puan he- 
saplanmıştır. Erkeklerin ve kadınların uyguladığı fiziksel şiddete yönelik tutumlar için Cronbach alfa iç tutarlılık katsayıları ön-testte sirasiyla .87 ve .82 , son-testte ise .86 ve .79 olarak hesaplanmıştır. Erkeklerin ve kadınların uyguladığı psikolojik şiddete yönelik tutumlar için ise Cronbach alfa iç tutarlılık katsayıları hem ön-test, hem son-testte sırasıyla .81 ve .83 olarak bulunmuştur. Yüksek puanlar flört şiddetine ilişkin daha kabullenici tutumları göstermektedir.

Sosyodemografik Bilgi Formu. Katılımc1ların demografik özellikleri ve flört deneyimleriyle ilgili bilgi toplamak için yazar tarafindan 20 sorudan oluşan bir form oluşturulmuş, ön-test ölçümünde uygulanmıştır. Katılımcılardan daha önce ve o sırada bir flört ilişkileri olup olmadı̆̆ı, önceki ve o sıradaki flört ilişkilerinin süresi, önceki flört ilişkilerinin sayısı hakkında bilgi toplanmıştır.

\section{Bulgular}

Bu çalışmada katılımcılar deney ve kontrol gruplarına seçkisiz olarak atanamamıştır. Bu nedenle ilk olarak deney ve kontrol gruplarının flört ve şiddet deneyimleri bakımından farklılaşıp farklılaşmadığı araştırılmıştır. Deney ve kontrol gruplarındaki katılımcıların sırasıyla \% 83'ü $(n=34)$ ve \% 71'i $(n=36)$ daha önce en az üç ay sürmüş bir flört ilişkisi yaşamıştır. Program başlangıcında ise bu grupların sirasiyla \% 54'ü $(n=22)$ ve \% 45'inin $(n=22)$ bir flört ilişkisi vardır. Yapılan ki kare analizleri deney ve kontrol grubu arasında flört deneyimleri bak1mından istatistiksel olarak anlamlı bir fark olmadığını göstermiştir. Katılımcıların önceki flört şiddeti deneyimlerini değerlendirmek için ÇÇYÇ puanlarına bakılmıştır. Buna göre katılımcıların son bir yıl içinde gösterdiği ve maruz kaldığı şiddet davranışlarının sayısı deney grubu için sırasıyla ortalama $3.61(S S=3.11)$ ve $3.80(S S=$ $3.19)$, kontrol grubu için sirasiyla $2.81(S S=2.11)$ ve 2.71 'dir $(S S=2.31)$. Yapılan bağımsız gruplar için $t$-test analizleri şiddet uygulama ve şiddete maruz birakılma bakımından gruplar arasında programdan önce anlamlı bir fark olmadığını göstermiştir.

İkinci olarak, deney ve kontrol grupları arasında programdan önce ölçek puanları bakımından istatistiksel olarak anlamlı bir fark olup olmadığ 1 araştırılmıştır. Tüm ön-test ölçümlerine (İIÇÇTÖ, ÇDCÖ-Düşmanca, ÇDCÖ-Korumac1, FŞTÖ-Fiziksel-E, FŞTÖ-Fiziksel-K, FŞTÖ-Psikolojik-E, FŞTÖ-Psikolojik-K) uygulanan bağımsız gruplar için $t$-test analizleri, deney ve kontrol grubu arasında programdan önce anlamlı bir fark olmadığını göstermiştir (Tablo 3).

Programın etkisini değerlendirmek için bir dizi 2 (Zaman: ön-test, son-test) x 2 (Grup: deney, kontrol) x 2 (Cinsiyet: kadın, erkek) karışık faktöriyel varyans analizi yapılmıştır. Analiz sonuçları Tablo 4'de sunulmuştur.

\section{Programın Yapıcı Çatışma Çözme Becerisi Üzerindeki Etkisi}

Programın yapıcı çatışma çözme becerisi üzerindeki etkisini araştırmak için İİÇÇTÖ puanlarına karışık faktöriyel varyans analizi uygulanmıştır. Analiz sonuçlarına göre Grup, Zaman ve Cinsiyet temel etkisinin anlamlı olmadığ tespit edilmiştir. Buna ek olarak, ikili ve üçlü ortak etkilerin de istatistiksel olarak anlamlı olmadığı bulunmuştur.

\section{Programın Cinsiyetçi Tutumlar Üzerindeki Etkisi}

Programın cinsiyetçi tutumlar üzerindeki etkisini araştırmak için ÇDCÖ-Düşmanca Cinsiyetçilik puanlarına karışık faktöriyel varyans analizi uygulanmıştır. Analiz sonuçlarına göre Grup temel etkisi istatistiksel olarak anlamlı değildir. Zaman temel etkisi ise istatistiksel olarak anlamlıdır $\left(\mathrm{F}_{1,86}=8.17, p=.005\right.$, klsmi $\eta^{2}=$ .08). Buna göre ön-test ÇDÇÖ-Düşmanca Cinsiyetçilik puan1 $($ Ort. $=2.62, S S=1.09)$ son-test puanından (Ort. $=2.46, S S=1.07)$ anlamlı olarak yüksektir. Ayrıca Cinsiyet temel etkisi de istatistiksel olarak anlamlıdır $\left(\mathrm{F}_{1,86}\right.$ $=7.47, p=.01$, kısmi $\eta^{2}=.08$ ). Buna göre erkeklerin ÇDÇÖ-Düşmanca Cinsiyetçilik puanı (Ort. $=2.82, S S=$ 1.06) kadinlardan $(O r t .=2.25, S S=1.01)$ anlamlı olarak daha yüksektir. Analiz Zaman x Grup etkileşiminin istatistiksel olarak anlamlı olduğunu göstermiştir $\left(\mathrm{F}_{1,86}\right.$ $=5.81, p=.02$, klsmi $\eta^{2}=.06$ ). Buna göre deney grubunun ÇDÇÖ-Düşmanca Cinsiyetçilik puanları ön-test ölçümünde (Ort. $=2.48, S S=1.10)$ son-teste göre daha yüksekken $($ Ort. $=2.19, S S=1.02)$, kontrol grubunda ön-test $($ Ort. $=2.72, S S=1.08)$ ve son-test $($ Ort. $=2.69$, $S S=1.07$ ) arasında anlamlı bir fark bulunmamıştır (bkz. Şekil 1). Diğer ikili (Zaman x Cinsiyet, Grup x Cinsiyet) ve üçlü (Zaman x Grup x Cinsiyet) ortak etkiler ise istatistiksel olarak anlamlı değildir.

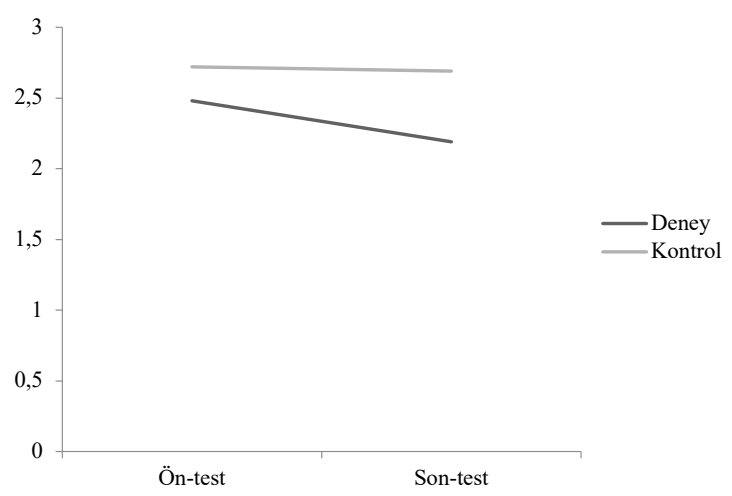

Şekil 1. ÇDÇÖ-Düşmanca Cinsiyetçilik için Zaman (Öntest, Son-test) x Grup (Deney, Kontrol) Ortak Etkisi 
Tablo 3. Grup ve Cinsiyete göre Betimleyici İstatistikler ve Gruplar Arası Karşılaştırma

\begin{tabular}{|c|c|c|c|c|c|c|}
\hline & & \multicolumn{2}{|c|}{$\begin{array}{c}\text { Deney Grubu } \\
\text { Ön-test }(n=41)\end{array}$} & \multicolumn{2}{|c|}{$\begin{array}{c}\text { Kontrol Grubu } \\
\text { Ön-test }(\mathrm{n}=49)\end{array}$} & \multirow[b]{2}{*}{$t$} \\
\hline & & M & SS & M & SS & \\
\hline \multirow{3}{*}{ İİÇÇTÖ } & Kadın & 6.51 & 1.03 & 6.41 & 1.03 & \\
\hline & Erkek & 6.61 & 0.88 & 6.31 & 1.21 & \\
\hline & Toplam & 6.55 & 0.96 & 6.36 & 1.12 & -0.87 \\
\hline \multirow[t]{3}{*}{ ÇDCÖ-Düşmanca } & Kadın & 2.39 & 1.04 & 2.25 & 1.01 & \\
\hline & Erkek & 2.61 & 1.20 & 3.21 & 0.96 & \\
\hline & Toplam & 2.48 & 1.10 & 2.72 & 1.08 & 1.04 \\
\hline \multirow[t]{3}{*}{ ÇDCÖ-Korumacı } & Kadın & 2.35 & 1.05 & 2.55 & 1.03 & \\
\hline & Erkek & 2.66 & 1.27 & 3.01 & 0.91 & \\
\hline & Toplam & 2.48 & 1.14 & 2.78 & 0.99 & 1.31 \\
\hline \multirow[t]{3}{*}{ FŞTÖ-Fiziksel-E } & Kadın & 1.20 & 0.32 & 1.19 & 0.38 & \\
\hline & Erkek & 1.43 & 0.43 & 1.44 & 0.44 & \\
\hline & Toplam & 1.32 & 0.06 & 1.32 & 0.06 & 0.22 \\
\hline \multirow[t]{3}{*}{ FŞTÖ-Fiziksel-K } & Kadın & 1.54 & 0.70 & 1.45 & 0.50 & \\
\hline & Erkek & 1.85 & 0.67 & 1.69 & 0.63 & \\
\hline & Toplam & 1.69 & 0.10 & 1.57 & 0.09 & -.68 \\
\hline \multirow[t]{3}{*}{ FŞTÖ-Psikolojik-E } & Kadın & 1.59 & 0.41 & 1.47 & 0.39 & \\
\hline & Erkek & 2.03 & 0.52 & 1.91 & 0.47 & \\
\hline & Toplam & 1.81 & 0.07 & 1.69 & 0.06 & -.79 \\
\hline \multirow[t]{3}{*}{ FŞTÖ-Psikolojik-K } & Kadın & 1.62 & 0.55 & 1.45 & 0.39 & \\
\hline & Erkek & 1.97 & 0.67 & 1.93 & 0.54 & \\
\hline & Toplam & 1.79 & 0.09 & 1.69 & 0.08 & -.61 \\
\hline
\end{tabular}

Notlar İ̇ÇTÖ: İkili İlişkilerde Çatışma Çözme Tepkileri Ölçeği, ÇDCÖ-Düşmanca: Çelişik Duygulu Cinsiyetçilik Ölçeği-Düşmanca Cinsiyetçilik, ÇDCÖ-Korumacı: Çelişik Duygulu Cinsiyetçilik Ölçeği-Korumacı Cinsiyetçilik, FŞTÖ-Fiziksel-E: Erkeğin Flörtte Uyguladığı Fiziksel Şiddete İlişkin Tutum Ölçeği, FŞTÖ-Fiziksel-K: Kadının Flörtte Uyguladığı Fiziksel Şiddete İlişkin Tutum Ölçeği, FŞTÖ-Psikolojik-E: Erkeğin Flörtte Uyguladığı Psikolojik Şiddete İlişkin Tutum Ölçeği, FŞTÖ-Psikolojik-K: Kadının Flörtte Uyguladığı Psikolojik Şiddete İlişkin Tutum Ölçeği.

ÇDCÖ-Korumacı Cinsiyetçilik puanlarına uygulanan karışık faktöriyel varyans analizi sonuçlarına göre Grup temel etkisi istatistiksel olarak anlamlı değildir. Zaman temel etkisi ise istatistiksel olarak anlamlıdır $\left(\mathrm{F}_{1,86}=51.55, p=.001, k u s m i \eta^{2}=.37\right)$. Buna göre ön-test ÇDÇÖ-Korumacı Cinsiyetçilik puanı (Ort. $=2.64, S S=$ 1.07) son-test puanından (Ort. $=2.19, S S=0.95)$ anlam11 olarak yüksektir. Cinsiyet temel etkisi de istatistiksel olarak anlamlı değildir. Ayrıca ikili ve üçlü ortak etkilerin de istatistiksel olarak anlamlı olmadığı bulunmuştur.

\section{Programın Flört Şiddetine Yönelik Tutumlar Üzerindeki Etkisi}

Programın fiziksel şiddete yönelik tutumlar üzerindeki etkisini araştırmak için FŞTÖ-Fiziksel-E ve
FŞTÖ-Fiziksel-K puanlarına karışık faktöriyel varyans analizi uygulanmıştır. FŞTÖ-Fiziksel-E puanları için Grup ve Zaman temel etkisi istatistiksel olarak anlamlı değildir. Cinsiyet temel etkisinin ise istatistiksel olarak anlamlı olduğu bulunmuştur $\left(\mathrm{F}_{1,85}=7.17, p=.01\right.$, kısmi $\left.\eta^{2}=.08\right)$. Buna göre erkeklerin FŞTÖ-Fiziksel-E puanları $($ Ort. $=1.38, S S=0.37)$ kadınlardan $($ Ort. $=1.19$, $S S=0.28$ ) daha yüksektir. Buna ek olarak, ikili ve üçlü ortak etkilerin istatistiksel olarak anlamlı olmadığı bulunmuştur.

FŞTÖ-Fiziksel-K puanlarına uygulanan karışık faktöriyel varyans analizi sonuçlarına göre Grup temel etkisi istatistiksel olarak anlamlı değildir. Zaman temel etkisi ise istatistiksel olarak anlamlıdır $\left(\mathrm{F}_{1,85}=20.86, p=.001, \mathrm{kls}\right.$ $\left.m i \eta^{2}=.19\right)$. Buna göre ön-test FŞTÖ-Fiziksel-K puanı 


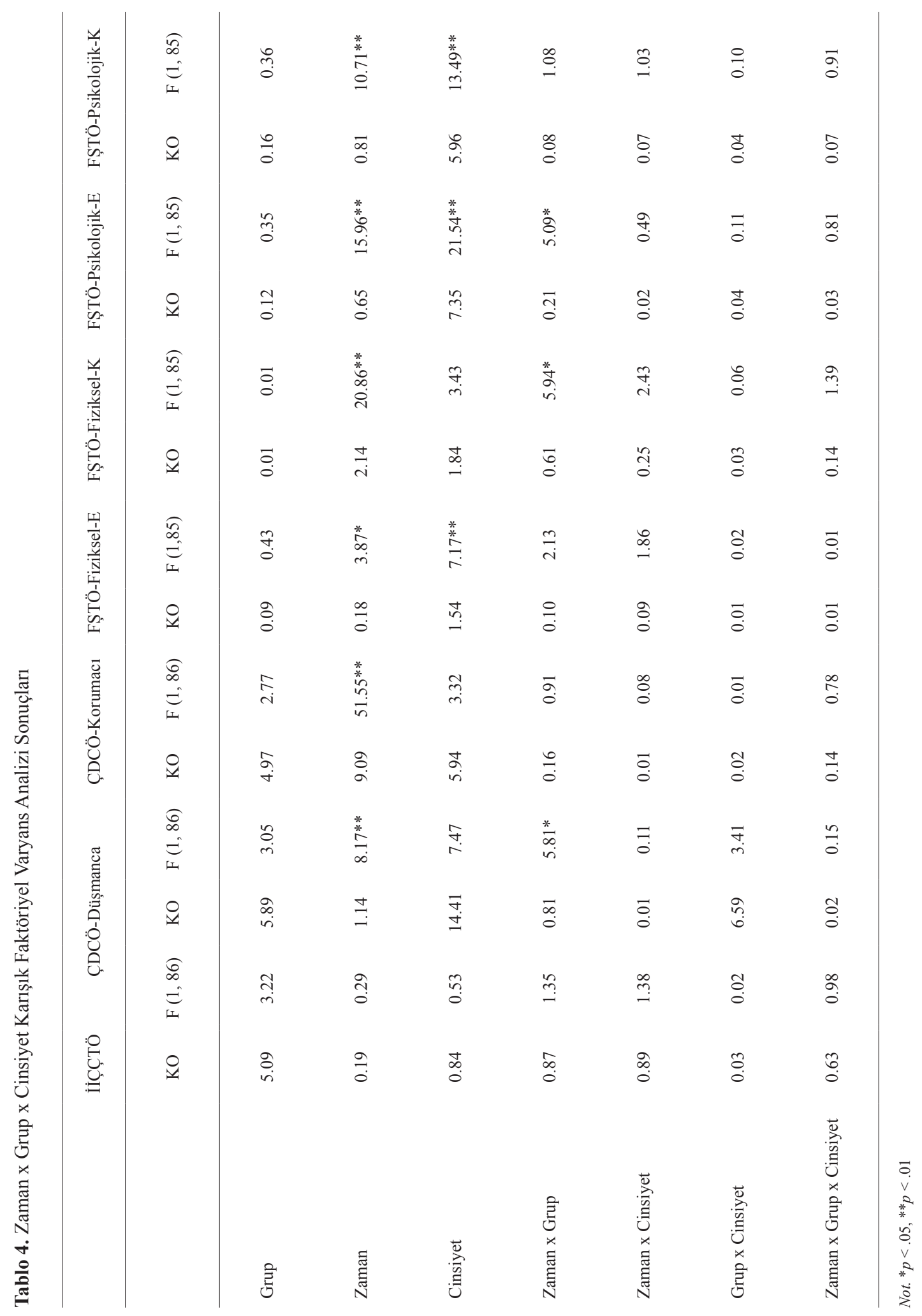


$($ Ort. $=1.63, S S=0.63)$ son-test puanından $($ Ort. $=1.41$, $\mathrm{SS}=0.49)$ anlamlı olarak yüksektir. Cinsiyet temel etkisi istatistiksel olarak anlamlı değildir. Analiz Zaman x Grup etkileşiminin istatistiksel olarak anlamlı olduğunu göstermiştir $\left(\mathrm{F}_{1,85}=5.94, p=.02\right.$, klsmi $\left.\eta^{2}=.06\right)$. Buna göre, deney grubunun FŞTÖ-Fiziksel-K puanları ön-test ölçümünde $($ Ort. $=1.69, S S=0.69)$ son-test ölçümünden (Ort. $=1.35, S S=0.47)$ daha yüksekken, kontrol grubunda öntest $($ Ort. $=1.57, S S=0.58)$ ve son-test $($ Ort. $=1.47, S S=$ 0.52 ) arasında anlamlı bir fark bulunmamıştır (bkz. Şekil 2). Diğer ikili (Zaman x Cinsiyet, Grup x Cinsiyet) ve üçlü (Zaman x Grup x Cinsiyet) ortak etkiler ise istatistiksel olarak anlamlı değildir.

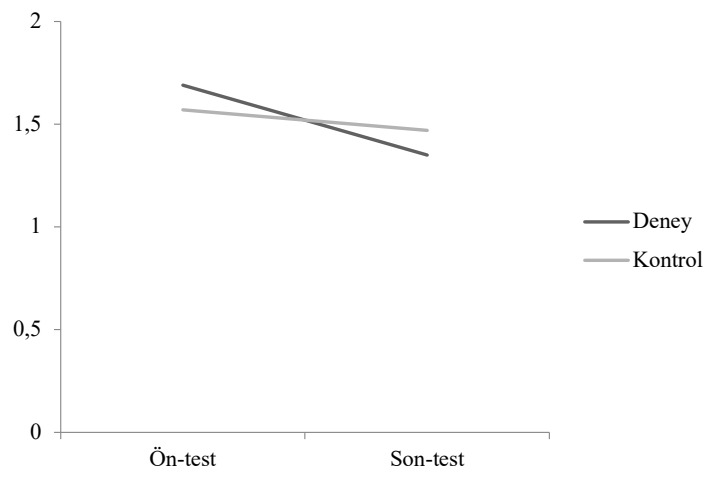

Şekil 2. FŞTÖ-Fiziksel-K için Zaman (Ön-test, Son-test) x Grup (Deney, Kontrol) Ortak Etkisi

Programın psikolojik şiddete yönelik tutumlar üzerindeki etkisini araştırmak için FŞTÖ-Psikolojik-E ve FŞTÖ-Psikolojik-K puanlarına karışık faktöriyel varyans analizi uygulanmıştır. FŞTÖ-Psikolojik-E puanları için Grup temel etkisi istatistiksel olarak anlamlı değildir. Zaman temel etkisi ise istatistiksel olarak anlamlıdır $\left(\mathrm{F}_{1,85}=15.96, p=.001\right.$, klsmi $\left.\eta^{2}=.16\right)$. Buna göre ön-test FŞTÖ-Psikolojik-E puanı (Ort. $=1.75, S S=0.49)$ sontest puanından $($ Ort. $=1.63, S S=0.47)$ anlamlı olarak yüksektir. Ayrıca Cinsiyet temel etkisi de istatistiksel olarak anlamlıdir $\left(\mathrm{F}_{1,85}=21.54, p=.01\right.$, klsmi $\left.\eta^{2}=.20\right)$. Buna göre erkeklerin FŞTÖ-Psikolojik-E puanı (Ort. = $1.89, S S=0.47)$ kadınlardan $($ Ort. $=1.48, S S=0.38)$ anlamlı olarak daha yüksektir. Analiz Zaman x Grup etkileşiminin de istatistiksel olarak anlamlı olduğunu göstermiştir $\left(\mathrm{F}_{1,85}=5.09, p=.03\right.$, klsmi $\left.\eta^{2}=.06\right)$. Buna göre, deney grubunun FŞTÖ-Psikolojik-E puanları ön-test ölçümünde $($ Ort. $=1.81, S S=0.50)$ son-teste göre $($ Ort. $=$ $1.62, S S=0.46)$ daha yüksekken, kontrol grubunda öntest $($ Ort. $=1.69, S S=0.48)$ ve son-test $($ Ort. $=1.64, S S=$ 0.48) arasında anlamlı bir fark bulunmamıştır (bkz. Şekil 3). Diğer ikili (Zaman x Cinsiyet, Grup x Cinsiyet) ve üçlü (Zaman x Grup x Cinsiyet) ortak etkiler ise istatistiksel olarak anlamlı değildir.

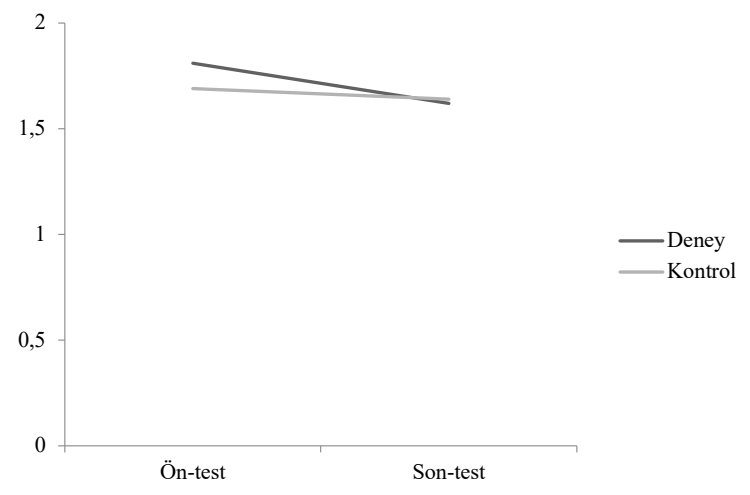

Şekil 3. FŞTÖ-Psikolojik-E için Zaman (Ön-test, Sontest) x Grup (Deney, Kontrol) Ortak Etkisi

FŞTÖ-Psikolojik-K puanları için Grup temel etkisi istatistiksel olarak anlamlı değildir. Zaman temel etkisi ise istatiksel olarak anlamlidır $\left(\mathrm{F}_{1,85}=10.71, p=.001\right.$, kısmi $\left.\eta^{2}=.11\right)$. Buna göre ön-test FŞTÖ-Psikolojik-K puan1 $($ Ort. $=1.74, S S=0.57)$ son-test puanından $($ Ort. $=$ $1.61, S S=0.49)$ anlamlı olarak yüksektir. Cinsiyet temel etkisinin de istatistiksel olarak anlamlı olduğu bulunmuştur, $\left(\mathrm{F}_{1,85}=13.49, p=.01\right.$, kısmi $\left.\eta^{2}=.13\right)$. Buna göre erkeklerin FŞTÖ-Psikolojik-K puanı (Ort. $=1.86, S S=$ $0.51)$ kadınlardan $($ Ort. $=1.49, S S=0.44)$ anlamlı olarak yüksektir. Analiz sonuçları ikili ve üçlü ortak etkilerin ise istatistiksel olarak anlamlı olmadığını göstermiştir.

\section{Tartıșma}

Bu çalışma üniversite öğrencilerine yönelik bir flört şiddeti önleme programı geliştirmeyi ve bu programın İstanbul'daki bir devlet üniversitesine devam etmekte olan bir grup öğrencinin davranış ve tutumları üzerindeki etkisini araştırmayı hedeflemiştir. Bu amaçla, flört şiddeti konusundaki farkındalığı artıracak, güvenli ve eşitlikçi ilişkiler kurma konusunda destek sunacak ve yapıcı çatışma çözme becerilerini geliştirecek bir flört şiddeti önleme programı hazırlanmıştır. Çalışmanın sonuçları, programın yapıcı çatışma çözme becerisi üzerinde bir etkisinin olmadığını, tutum değişiklikleri yaratmada ise kısmen etkili olabildiğini göstermiştir. Bu çalışma, Türkiye'de flört şiddetini önleme konusunda bir program ortaya koyan ve etki değerlendirmesini yapan ilk çalışmalardan olması bakımından ulusal alan yazına bir katkı sağlamaktadır. Bu çalışma ile sonraki araştırmalarda kullanılabilecek bir uygulama örneği sunulmakta ve kadına yönelik şiddete ilişkin önleyici yaklaşımların önemi vurgulanmaktadır. 
Çalışmanın bulguları programdan sonra deney grubunda yapıcı çatışma çözme becerilerinin artacağı yönündeki hipotezi desteklememiş, bu beceride anlamlı düzeyde bir gelişme saptanamamıştır. Bu bulgular, alan yazında flört şiddetini önleme programlarının iletişim ve çatışma çözme becerileri üzerindeki olumlu etkilerini gösteren çalışmalarla (Ball ve ark., 2012; Foshee ve ark., 1998, 2000) uyumsuzdur. Bu uyumsuzluğun bir nedeni hazırlanan programın içeriği, kapsamı veya süresinin yetersiz olması olabilir. Bu çalışmada hazırlanan program, çatışma çözme becerilerini geliştirmenin yanı sıra flört şiddetine ilişkin tutumları değiştirmeyi ve flört şiddeti konusunda farkındalığı artırmayı hedeflemiştir. Söz konusu beceriler deney grupları içinde güvenlik ve şiddet konuları bağlamında ele alınmış ve canlandırmalarla desteklenmiștir. Bu tür faaliyetlere ayrılan zaman deney grubunda beklenen davranışsal değişimi yaratmak için yeterli olmayabilir. Örneğin, çatışma çözme becerisinde istatistiksel olarak anlamlı bir gelişme yaratabilen Güvenli Flört programı 10 oturumluk bir programdır ve lise düzeyindeki öğrencilerle yapılan çalışmaların yanı sıra okul iklimini değiştirmeye yönelik müdahaleleri de içermektedir (Foshee ve ark., 1998, 2000). Benzer şekilde, çatışma çözme becerisinde olumlu değişimler yarattığ grubu niteliğindedir ve bireysel yaşantıların paylaşımı$\mathrm{n} 1$ içerir (Ball ve ark., 2009). Nation ve arkadaşları da (2003) inceledikleri bir dizi önleyici programın beklenen yönde bir etki doğurabilmesi için yeterli dozda müdahale içermesi gerektiğini bildirmiştir. Bu çalışma kapsamında geliştirilen programın çatışma çözme becerisi üzerinde olumlu bir etkisi olmasını sağlamak için program süresinin uzatılması, bireysel deneyimlere daha fazla zaman ayrılması ve daha fazla rehberlik ve pratik yapma olanağı sağlanması sonraki çalışmalarda yapılması gereken değişiklikler arasındadır.

Çatışma çözme becerilerinde herhangi bir gelişme görülmemesinin bir diğer nedeni çalışmanın yöntemsel sınırlılıkları olabilir. Bu çalışmada yapıcı çatışma çözme becerisindeki değişim 8 haftalık bir zaman aralığıyla ölçülmüştür. Ölçekleri dolduran bazı katılımcılar ön-test ve son-test ölçümleri arasında bu becerileri kullanmalarını gerektirecek bir durum yaşamadıklarını ifade etmiştir. Yapıcı çatışma çözme becerisinde programa bağlı bir değişim olsa dahi bu kısa zaman aralığı, bu etkinin ortaya çıkması için yeterli olmayabilir. Bu bakımdan izleme ölçümlerinin alınamaması çalışma için önemli bir sınırlılık olmuştur. Buna ek olarak, program birincil önleme hedefi taşıdığından flört ilişkisi olmayan katılımcılar da programa davet edilmiştir. Bu katılımcıların ölçeği doldururken yakın arkadaşlık ilişskilerini düşünmeleri istenmiştir, ancak bu durum bazı ölçek maddelerini değerlendirmeyi zorlaştırmış olabilir. Wolfe ve arkadaşları
(2003) tarafından yürütülen boylamsal bir çalışmada bu tür yöntemsel sınırlılıkları aşmak için önleme programına katılan gençler 2 aylık düzenli aralıklarla araştırmacılar tarafindan telefonla aranmış, bir katılımcı yeni bir flört ilişkisine başladığında çeşitli ölçümler alınarak katılımıının ilişski içindeki davranışları takip edilmiştir. $\mathrm{Bu}$, emek-yoğun bir veri toplama süreci olsa da bu tür boylamsal çalışmaların artması önleme çalışmalarının etkilerini tespit etmede büyük fayda sağlayacaktır. Alan yazındaki diğer araştırmacılar ise yapıcı çatışma çözme veya şiddet uygulama gibi davranışlardaki değişimi saptamak için yalnızca öz-bildirime dayalı ölçekleri kullanmanın yanı sıra derinlemesine görüşme, doğrudan gözlem ve partner değerlendirmeleri gibi çeşitli veri toplama yöntemlerinin bir arada kullanılmasını önermişlerdir (Cornelius ve Resseguie, 2007; O'Leary ve ark., 2006; Pittman ve ark., 2000; Wekerle ve Tanaka, 2010). Sonraki araştırmalarda etki değerlendirmesi için bu öneriler doğrultusunda çeşitli kaynaklardan bilgi toplanması önemli bir adım olacaktır.

$\mathrm{Bu}$ çalışmada, uygulanan programın deney grubunda cinsiyetçi tutumları azaltacağı yönündeki ikinci hipotez kısmen destek bulmuştur. Çalışmanın bulguları, deney grubunda düşmanca cinsiyetçilik tutumunun programdan sonra azaldığını gösterirken korumacı cinsiyetçilik tutumunda herhangi bir değişiklik saptanamamıştır. Düşmanca cinsiyetçilik tutumundaki azalma, alan yazındaki diğer araştırmalarla (Foshee ve ark.,1998, 2000; Schwartz ve ark., 2004, 2006) ve program süresince yapılan gözlemlerle paralellik göstermektedir. Düşmanca cinsiyetçilik tutumunun şiddete ilişkin tutum (Sakallı-Uğurlu ve Ulu, 2003) ve davranışlar (Hüsnü ve Mertan, 2017) üzerindeki yordayııı etkisi düşünüldüğünde, bu değişimin olumlu bir adım olduğu söylenebilir. Bu değişimin oluşmasında güç eşitliği ve toplumsal cinsiyet rollerine ilişkin faaliyetler kadar grup içi süreçlerin de etkili olduğu düşünülmektedir. Çalışma sonunda deney gruplarındaki katılımcılar karma bir grup içinde kadın ve erkeklerle bir arada çalışmanın ve flört şiddeti ve ilişkiler konusunda "karşı cinsin" görüşlerini öğrenmenin faydalı olduğunu dile getirmiş; bir arada çalışmanın cinsiyetler arası kutuplaşmayı engellediğini ve benzerliklerin fark1na varmayı sağladığını ifade etmiştir. Grup içi olumlu ilişkiler ayrımcı ve düşmanca tutumların beklenen yönde değişmesine katkıda bulunmuş olabilir. Benzer şekilde, önceki araştırmalar genç kadın ve erkeklerin karma grupları tercih ettiğini (Elias-Lambert, Black ve Sharma, 2010), bu gruplarda gençlerin birbirlerinin bakış açısını öğrenme olanağı bulduğunu (Kerig ve ark., 2010) ve bu sayede gruba ilgi ve bağlılığın arttığını (Wolfe ve ark., 1996) bildirmiştir. Sonraki çalışmalarda, önleyici programların karma gruplara yönelik hazırlanması ve uygulanmasının avantajları dikkate alınmalıdır. 
Korumacı cinsiyetçilik tutumunda programdan sonra herhangi bir değişim görülmemesinin bir nedeni, bu cinsiyetçilik biçiminin "olumlu" gibi algılanması olabilir (Glick ve Fiske, 1996; Glick ve ark., 2000). Korumacı cinsiyetçilik, erkeklerin kadınlara yönelik korumac1 ve sahiplenici tutumlarını içerir ve güçlü erkek imajı ile korunmaya muhtaç, güçsüz ve kırılgan kadın imajı arasındaki güç eşitsizliğini görünmez kılar (Glick ve Fiske, 1996). Bu nedenle bu tür tutumların farkına varmak düşmanca cinsiyetçiliğe oranla daha zor olabilir. Türkiye gibi cinsiyetçi toplumlarda düşmanca cinsiyetçilik tutumu reddedilse dahi, korumacı cinsiyetçilik tutumu sevgi ve koruyuculuk adı altında kontrolcü davranışları, eşitsiz ilişkileri ve geleneksel toplumsal cinsiyet rollerini meşru göstermekte ve pekiştirmekte; bu tür tutumlar özellikle kadınlar arasında yaygın şekilde destek bulmaktadır (Glick ve ark., 2000). Buna ek olarak, korumac1 cinsiyetçiliği tanımlayan kadını yüceltme, tamamlayıcı rolünü vurgulama, sevgi ve ihtiyaç duygularını yansıtma gibi özellikler (Glick ve Fiske, 1997; Sakall1-Uğurlu, 2002) romantize ve idealize edilen aşk tanımıyla örtüşmektedir. Heteroseksüel ve romantik aşk idealleri gençlerin flört ilişkileriyle ilgili algısını şekillendirmekte ve erkeğin baskın konumunu romantize etmektedir (Papp, Liss, Erchull, Godfrey ve Waaland-Kreutzer, 2017). Önceki çalışmalar hem korumacı cinsiyetçiliğin (Sakallı-Uğurlu ve Ulu, 2003), hem de romantik aşk ideallerinin (Jackson, 2001; Johnson ve ark., 2005) şiddete ilişkin kabullenici tutumları ve şiddete maruz kalma riskini artırdığını bildirmektedir. Bu nedenle, geliştirilen programa aşk ve sahiplenme kavramlarını daha derinlemesine tartışmaya açacak faaliyetlerin eklenmesi, bu kavramların şiddetle ilişkilerinin ortaya koyulması ve korumacı cinsiyetçiliği sarsacak mesajların üniversite çapında yürütülecek iletişim kampanyaları ile desteklenmesi etkinliği artırmak için yapılabilecek değişikliklerdir.

Bu çalışmada, programın deney grubunda flört şiddetine ilişskin kabullenici tutumları azaltacağı yönündeki üçüncü hipotez kısmen destek bulmuştur. Fiziksel flört şiddetine ilişkin bulgulara bakıldığında, kadınlar tarafından uygulanan fiziksel şiddeti kabullenici tutumlarda bir azalma olurken, erkekler tarafindan uygulanan fiziksel şiddete yönelik tutumlarda bir değişiklik olmamıştır. Bu sonuçlar, Jaycox ve arkadaşları (2006) tarafından yapılan çalışmanın bulgularıyla paraleldir. Araştırmacılar 3 günlük bir önleme programından sonra yalnızca kadınların uyguladığı fiziksel şiddete yönelik tutumlarda olumlu yönde değişiklik saptamıştır. Bu çalışmada erkeklerin fiziksel şiddet kullanımına ilişkin tutumlarda anlamlı bir değişim gözlenememesinin bir nedeni taban etkisi olabilir. Ortalamalara bakıldığında, bu tür şiddet davranışlarının çalışmaya katılan gençler arasında kabul görmediği göze çarpmaktadır. Ön-test ve son-test ölçümle- rinde katılımcılar ölçekteki bazı ifadelerden (örn. "Bazı kızlar erkek arkadaşları tarafından tokatlanmayı hak eder") duydukları rahatsızlığı dile getirmiş ve üniversite ortamında bu tür inançların yaygın olamayacağını ifade etmiştir. Kullanılan ölçeğin erkek şiddetiyle ilgili maddeleri çok olumsuz algılanmış ve bu ifadeler güçlü bir şekilde reddedilmiştir. Bu nedenle katılımcıların erkeklerin uyguladığı fiziksel flört şiddetine ilişkin tutumlarını değerlendiren FŞTÖ’nün örneklem özelliklerine uygun olmadığı düşünülmüştür. Sonraki çalışmalarda bu tutumları ölçmek için flört şiddeti konusunda senaryo değerlendirme gibi açık uçlu yöntemler kullanılabilir ve bu yöntemler erkek şiddetini meşru ve normal gösteren düşünce kalıplarını, inanç ve tutumları saptamada daha faydalı olabilir.

Psikolojik flört şiddetine ilişkin bulgulara bakıld1ğında, erkeklerin uyguladığı şiddete yönelik kabullenici tutumlar deney grubunda programdan sonra zayıflarken, kadınların uyguladığı şiddete yönelik tutumlarda bir değişiklik gözlenmemiştir. Önceki etki değerlendirme çalışmaları çoğunlukla fiziksel şiddete odaklandığından veya farklı şiddet biçimlerini ayrıştırmayan genel ölçekler kullandığından (Avery-Leaf ve ark., 1997; Krajewski ve ark., 1996; Kuffel ve Katz, 2002), bu bulgular alan yazına bir katkı sağlamakta, kadın ve erkeklerin uyguladığı psikolojik şiddete yönelik tutumların programlardan farkl1 şekilde etkilenebileceğine işaret etmektedir. Erkeğin uyguladığı psikolojik şiddeti kabullenici tutumların programdan sonra azalması düşmanca cinsiyetçilik tutumundaki değişimle paraleldir. Kadınlara yönelik ayrımcılık ile küçümseme ve saldırganlık içeren görüşler, erkeklerin kadınlar üzerindeki kontrolünü ve psikolojik baskısını normal ve meşru gösterir. Bu inançlardaki değişimin bir arada gerçekleşmesi beklenebilir. Buna karşın, kadınların uyguladığı psikolojik flört şiddetine yönelik tutumlarda bir değişimin olmaması önleme programının bu konudaki yetersizliğine işaret ediyor olabilir. Program sonrasında bazı katılımcılar psikolojik şiddete daha fazla zaman ayrılması gerektiği yönünde bir geri bildirimde bulunmuştur. Yapılan çalışmalar psikolojik şiddetin diğer şiddet biçimlerine oranla tanımlanmas1 daha güç bir kavram olduğunu (Murphy ve Hoover, 1999), kadınların psikolojik şiddete başvurmasının öfke, kıskançlık ve partnerin şiddetine karşı kendini savunma gibi pek çok farklı nedenden kaynaklandığını (Leisring, 2013) göstermiştir. Geliştirilen programın bu farklı deneyimleri kapsayacak şekilde genişletilmesi, psikolojik şiddetin daha derinlemesine ele alınması ve psikolojik şiddetin kadın ve erkek rolleriyle ilişkisinin irdelenmesi program etkinliğini artırmak için gerekli değişikliklerden bazıları olabilir.

$\mathrm{Bu}$ çalıșmanın bazı sınırlılıkları bulunmaktadır. Bunlardan ilki, katılımcıların deney ve kontrol grup- 
larına seçkisiz olarak atanamamış olmamasıdır. Buna neden olan ve önceki bölümde açıklanan sınırlılıkların (bırakma oranı, zaman kısıtlılığı) sonraki çalışmalarda ele alınması daha güvenilir karşılaştırmaların yapılabilmesi için büyük önem teşkil etmektedir. Bu amaçla örneklem seçiminde birden fazla üniversitede daha çok sayıda öğrenciye ulaşılması hedeflenebilir. İkincisi, bu araştırmada uzun süreli bir izleme çalışmasının yapılamamış olmasıdır. Programdan sonra deney grubunun tutumlarında meydana gelen olumlu değişimlerin uzun vadede ne ölçüde korunabileceği önemli bir araştırma sorusudur. Üçüncü olarak, bu çalışma İstanbul'daki bir devlet üniversitesinde okuyan öğrencilerle gerçekleştirilmiş, farklı üniversite yerleşkelerinde uygulanmamıştır. Üniversite kültürleri birbirinden farklılık gösterebildiği için bu çalışmada elde edilen bulgularla ilgili genelleme yapılmamalı, sonraki araştırmalarda programın farklı öğrenci grupları üzerindeki etkisi araştırılmalıdır. Dördüncü olarak, çalışmadaki örneklemin çoğunluğu kadınlardan oluşmaktadır. Konuya ilgi duyan ve programa zaman ayırmak isteyen erkek öğrenci sayısının daha az olduğu gözlenmiştir. Bu durum, elde edilen bulguların genellenebilirliği bakımından bir sınırlılık oluşturmaktadır. Sonraki çalışmalarda erkeklerin katılım süreçleri ve motivasyonlarının araştırılması daha geniş ve temsili bir örnekleme ulaşmak için önem taşımaktadır.

Beşinci olarak, programın flört şiddeti davranıșları üzerindeki etkisi bu çalışma kapsamında değerlendirilememiştir. Çalışmanın hedefi birincil önleme olduğundan çalışmaya katılmak isteyen gençler flört ilişkisi olup olmadığına veya flört şiddeti yaşayıp yaşamadığına bakılmaksızın davet edilmiştir. Sonraki çalışmalarda daha büyük örneklemlerle çalışarak bu etkilerin araştırılması önemli olacaktır. Altıncı olarak, programı tamamlayan bazı katılımcilar gruba ek puan almak, yeni insanlar tanımak gibi beklentilerle katıldığını bildirmiştir. Bu katılımcılar az sayıda olsa da, bu tür beklentilerle katılmış olmaları gruba bağlılığın oluşmasını ve grup dinamiklerini zaman zaman olumsuz yönde etkilemiş olabilir. Sonraki çalışmalarda, flört şiddeti konusunda risk altında olan veya program konularına ilgi duyup ilişkiler konusunda düşünmek isteyen öğrencilerin hedef alınması s1nırlı kaynakların doğru kullanılmasını sağlayabilir. Son olarak, programın bazı tutumlar üzerindeki olumlu etkisi değerlendirilirken ihtiyatlı olunmalıdır. Son-test ölçümlerinde özellikle deney grubundaki katılımcılar, araştırmacıyı memnun etme isteğiyle beklenen yönde yanıtlar verme eğilimi göstermiş olabilirler. Bu tür etkilerin azaltılması için program süresince araştırmaya ilişkin sorular yanıtlanmamış, ancak veri toplama sürecinden sonra bilgilendirme yapılmıştır. Buna rağmen, sonuçlar yorumlanırken potansiyel karıștırıcı etkiler göz önünde bulundurulmalıdır. Sonraki çalışmalarda programı uygulama ve veri toplama süreçlerini farklı araştırmacıların yürütmesi bu tür etkileri azaltmaya yardımcı olabilir.

$\mathrm{Bu}$ çalışmada programın ölçülebilen etkileri sınırlı olsa da bulguların umut verici olduğu düşünülmektedir. Çalışmada flört ilişkilerinde şiddet uygulama ve şiddete maruz bırakılma deneyimleri sınırlı olan bir öğrenci grubuyla çalışılmıştır. Program süresince bu grubun edindiği bilgi ve farkındalığın sonraki ilişkileri için koruyucu bir etmen olacağı düşünülmektedir. Sonraki çalişmalarda bu program daha önce flört şiddeti deneyimi olan gençlere uygulanabilir ve müdahalelerin etkisi bu yolla değerlendirilebilir. Bu çalışma kapsamında elde edilen bulgulardan ve yapılan gözlemlerden yola çıkılarak sonraki çalışmalarda şu adımların atılması flört şiddetinin önlenmesine katkıda bulunacaktır: 1) Üniversite ortamında flört ilişskileri konusundaki çalışmalara devam edilmesi; grup-temelli programların yanı sıra eşitlik ve şiddetsizlik düşüncesini yerleşke kültürünün bir unsuru haline getirecek kapsamlı iletişim kampanyalarının yürütülmesi; 2) İdeal ve romantik aşk söylemlerinin sorgulanması, bu söylemlerin toplumsal cinsiyet eşitsizliği ve şiddetle ilişkisinin irdelenmesi, aşkın eşitlik ve güvenlikle ilişkilendirilerek yeniden tanımlanması; 3) Flört şiddetinin farklı biçimleri konusunda farkındalığın artırılması ve şiddeti normalleştiren tutumların hedef alınması, psikolojik şiddete vurgu yaparak bu konuda bilgilendirici müdahalelerin yürütülmesi; 4) Gençlerin çatışma çözme gibi sosyal ve ilişkisel becerilerinin gelişimini destekleyen ortamların oluşturulması; 5) Kadın ve erkek katılımcıların bir arada çalışmasını sağlayacak programların geliştirilmesi; genç kadın ve erkeklerin karşılıklı, işlevsel ve etkili iletişim kurabileceği sosyalleşme deneyimlerinin oluşturulması. Bu bulgu ve önerilerin sonraki flört şiddeti önleme çalışmaları için bir başlangıç olması umut edilmektedir. 


\section{Kaynaklar}

Aba, Y. A. (2008). Çatışmaların çözümüne yaklaşım ölçeği'nin "the revised conflict tactics scale (CTS2)" üniversite ögrrencilerinde geçerlik ve güvenirlik çalışması. Yayınlanmış yüksek lisans tezi, Akdeniz Üniversitesi, Antalya, Türkiye.

Aba, Y. A., \& Kulakaç, Ö. (2016). Çatışmaların çözümüne yaklaşım ölçeği: Geçerlik ve güvenirlik çalışmas1. Bakırköy Tıp Dergisi, 12(1), 32-43.

Antle, B. F., Sullivan, D. J., Dryden, A., Karam, E. A., \& Barbee, A. P. (2011). Healthy relationship education for dating violence prevention among high-risk youth. Children and Youth Services Review, 33(1), 173-179.

Aronson, K. M. R., \& Buchholz, E. S. (2001). The post-feminist era: Still striving for equality in relationships. The American Journal of Family Therapy, 29(2), 109-124.

Arslan, D. İ. (2002). Dating violence among Turkish university students: Prevalence rates and predictors of psychological, physical and sexual violence. Yayınlanmamış yüksek lisans tezi, Boğaziçi Üniversitesi, İstanbul, Türkiye.

Aslan, D. , Vefikulucay, D., Zeyneloğlu, S., Erdost, T. \& Temel, F. (2008). Ankara'da iki Hemșirelik Yüksekokulu'nun birinci ve dördüncü sınıflarında okuyan öğrencilerin flört şiddetine maruz kalma, flört ilişkilerinde şiddet uygulama durumlarının ve bu konudaki görüşlerinin saptanması araştırması. Ankara: Hacettepe Üniversitesi Kadın Sorunları Araştırma ve Uygulama Merkezi.

Avery-Leaf, S., Cascardi, M., O’Leary, K. D., \& Cano, A. (1997). Efficacy of a dating violence prevention program on attitudes justifying aggression. Journal of Adolescent Health, 21(1), 11-17.

Ball, B., Kerig, P. K., \& Rosenbluth, P. (2009). "Like a family but better because you can actually trust each other": The expect respect dating violence prevention program for at-risk youth. Health Promotion Practice, 10 (1 suppl), 45-58.

Ball, B., Tharp, A. T., Noonan, R. K., Valle, L. A., Hamburger, M. E., \& Rosenbluth, B. (2012). Expect respect support groups preliminary evaluation of a dating violence prevention program for at-risk youth. Violence against Women, 18(7), 746-762.

Belmont, J. A. (2006). 103 Group activities and treatment ideas and practical strategies. Eau Claire: Wisconsin Pesi Healthcare Llc.

Besni, İ. (2011). Üniversite ögrencilerinin aile içi şiddete yönelik tutumlarının cinsiyet, politik görüş ve şiddete maruz kalma açısından incelenmesi. Yayınlanmamış yüksek lisans tezi, Gaziosmanpaşa Üniversitesi, Tokat, Türkiye.
Bolak-Boratav, H., \& Çavdar, A. (2012). Sexual stereotypes and practices of university students in Turkey. Archives of Sexual Behavior, 41(1), 271-281.

Boyacıoğlu, İ. (2016). Dünden bugüne Türkiye'de kad1na yönelik şiddet ve ulusal kadın çalışmaları: Psikolojik araştırmalara davet. Türk Psikoloji Yazıları, 19(Özel Sayl), 126-145.

Brown, N. (2013). Creative activities for group therapy. New York: Routledge.

Ceylan, S., Doğulu, C., \& Akbaş, G. (2016). Namus adına kadına yönelik şiddete dair sosyal temsiller: Karma yöntemli bir çalışma. Türk Psikoloji Yazılarl, 19(Özel Sayl), 50-60.

Cinal, B. (2018). Flört şiddeti ve flört şiddetine yönelik tutumun anksiyete ve depresyon düzeyleriyle ilişkisinin incelenmesi. Yayınlanmamıș yüksek lisans tezi, Işı1k Üniversitesi, İstanbul, Türkiye.

Collins, W. A., Welsh, D. P., \& Furman, W. (2009). Adolescent romantic relationships. Annual Review of Psychology, 60, 631-652.

Cornelius, T. L., \& Resseguie, N. (2007). Primary and secondary prevention programs for dating violence: A review of the literature. Aggression and Violent Behavior, 12(3), 364-375.

Çimen, O. (2018). Heteroseksüel gençlerin flört şiddetine yönelik söylemleri. Yayınlanmamıss yüksek lisans tezi, İstanbul Arel Üniversitesi, İstanbul, Türkiye.

Dikmen, H. A., Özaydin, T., \& Yılmaz, S. D. (2018). Üniversitedeki kadın öğrencilerde yaşanan flört şiddeti ile anksiyete ve umutsuzluk düzeyleri arasındaki ilişki. Acıbadem Üniversitesi Sağlık Bilimleri Dergisi, 9(2), 170-176.

Dobash, R. E., \& Dobash, R. P. (1984). The nature and antecedents of violent events. The British Journal of Criminology, 24(3), 269-288.

Elliott, S. (1994). Group activities for counselors. Spring Valley, California: Interchoice Publishers.

Enns, C. Z. (1992). Dilemmas of power and equality in marital and family counseling: proposals for a feminist perspective. İçinde R. L. Smith and P. Stevens-Smith (Ed.), Family Counseling and Therapy: Major Issues and Topics (syf. 338-358), Michigan, The US: ERIC Counseling and Personnel Services Clearinghouse.

Eshelman, L., \& Levendosky, A. A. (2012). Dating violence: Mental health consequences based on type of abuse. Violence and Victims, 27(2), 215-228.

Elias-Lambert, N., Black, B., \& Sharma, Y. (2010). Middle school youth: Satisfaction with and responses to a dating violence and sexual assault prevention program. Journal of School Violence, 9(2), 136-153. 
Fişek, G. O. (1995). Gender hierarchy: Is it a useful concept in describing family structure? İçinde J. van Lawick \& M. Sanders (Ed.), Family, Gender and Beyond (syf. 63-72). Heemstede, The Netherlands: LS Books.

Foshee, V. A., Bauman, K. E., Arriaga, X. B., Helms, R. W., Koch, G. G., \& Linder, G. F. (1998). An evaluation of Safe Dates: An adolescent dating violence prevention program. American Journal of Public Health, 88(1), 45-50.

Foshee, V. A., Bauman, K. E., Greene, W. F., Koch, G. G., Linder, G. F., \& MacDougall, J. E. (2000). The Safe Dates program: 1-year follow-up results. American Journal of Public Health, 90(10), 16-19.

Foshee, V. A., Bauman, K. E., Ennett, S. T., Linder, G. F., Benefield, T., \& Suchindran, C. (2004). Assessing the long-term effects of the Safe Dates program and a booster in preventing and reducing adolescent dating violence victimization and perpetration. American Journal of Public Health, 94(4), 619-624.

Foshee, V. A., Bauman, K. E., Ennett, S. T., Suchindran, C., Benefield, T., \& Linder, G. F. (2005). Assessing the effects of the dating violence prevention program "Safe Dates" using random coefficient regression modeling. Prevention Science, 6(3), 245-258.

Foshee, V. A., Reyes, H. L. M., Gottfredson, N. C., Chang, L. Y., \& Ennett, S. T. (2013). A longitudinal examination of psychological, behavioral, academic, and relationship consequences of dating abuse victimization among a primarily rural sample of adolescents. Journal of Adolescent Health, 53(6), 723-729.

Glick, P., \& Fiske, S. T. (1996). The ambivalent sexism inventory: Differentiating hostile and benevolent sexism. Journal of Personality and Social Psychology, 70(3), 491-512.

Glick, P., Fiske, S. T., Mladinic, A., Saiz, J. L., Abrams, D., Masser, B., Adetoun, B., Osagie, J. E., Akande, A., Alao, A., Brunner, A., Willemsen, T. M., Chipeta, K., Dardenne, B., Dijksterhuis, A., Wigboldus, D., Eckes, T., Six-Materna, I., Exposito, F., Moya, M., Foddy, M., Kim, H., Lameiras, M., Sotelo, M. J., Mucchi-Faina, A., Romani, M., Sakalli, N., Udegbe, B., Yamamoto, M., Ui, M., Ferreira, M. C., \& Lopez, W. L. (2000). Beyond prejudice as simple antipathy: Hostile and benevolent sexism across cultures. Journal of Personality and Social Psychology, 79(5), 763-775.

Glick, P., Lameiras, M., Fiske, S. T., Eckes, T., Masser, B., Volpato, C., Manganelli, A. M., Pek, J. C. X, Huang, L., Sakalli-Ugurlu, N., Castro, Y. R., Pereira, M. L.D., Willemsen, T. M., Brunner, A., Six-Materna, I., \& Wells, R. (2004). Bad but bold:
Ambivalent attitudes toward men predict gender inequality in 16 nations. Journal of Personality and Social Psychology, 86(5), 713-728.

Goldner, V. (1998). The treatment of violence and victimization in intimate relationships. Family Process, 37(3), 263-286.

Goldner, V. (1999). Morality and multiplicity: Perspectives on the treatment of violence in intimate life. Journal of Marital and Family Therapy, 25(3), 325-336.

Goldner, V. (2004). When love hurts: Treating abusive relationships. Psychoanalytic Inquiry, 24(3), 346372.

Husnu, S., \& Mertan, B. E. (2017). The roles of traditional gender myths and beliefs about beating on self-reported partner violence. Journal of Interpersonal Violence, 32(24), 3735-3752.

Jackson, S. (2001). Happily never after: Young women's stories of abuse in heterosexual love relationships. Feminism \& Psychology, 11(3), 305-321.

Jaffe, P. G., Sudermann, M., Reitzel, D., \& Killip, S. M. (1992). An evaluation of a secondary school primary prevention program on violence in intimate relationships. Violence and Victims, 7(2), 129-146.

Jaycox, L. H., McCaffrey, D., Eiseman, B., Aronoff, J., Shelley, G. A., Collins, R. L., \& Marshall, G. N. (2006). Impact of a school-based dating violence prevention program among Latino teens: Randomized controlled effectiveness trial. Journal of Adolescent Health, 39(5), 694-704.

Johnson, S. B., Frattaroli, S., Campbell, J., Wright, J., Pearson-Fields, A. S., \& Cheng, T. L. (2005). "I know what love means": Gender-based violence in the lives of urban adolescents. Journal of Women's Health, 14(2), 172-179.

Kepir-Savoly, D. D., Ulaş, Ö., \& Demirtaş-Zorbaz, S. (2014). Üniversite öğrencilerinin çiftler arası şiddeti kabul düzeylerini etkileyen etmenler. Türk Psikolojik Danışma ve Rehberlik Dergisi, 5, 173-183.

Kerig, P. K., Volz, A. R., Moeddel, M. A., \& Cuellar, R. E. (2010). Implementing dating violence prevention programs with flexibility, fidelity, and sensitivity to diversity: Lessons learned from Expect Respect. Journal of Aggression, Maltreatment and Trauma, 19(6), 661-680.

Kılınçer, A. S., \& Tuzgöl-Dost, M. (2014). Üniversite öğrencilerinin romantik ilişkilerinde algıladıkları istismar. Türk Psikolojik Danışma ve Rehberlik Dergisi, 5, 160-172.

Kilpatrick, S. D., Bissonnette, V. L., \& Rusbult, C. E. (2002). Empathic accuracy and accommodative behavior among newly married couples. Personal Relationships, 9(4), 369-393. 
Knudson-Martin, C. (2013). Why power matters: Creating a foundation of mutual support in couple relationships. Family Process, 52(1), 5-18.

Koberlein, L., Toth, G., Sartingen, P., Hahn, S., Krohe-Amann, A., Gaiser, H., Stanic, T., Rösslhummer, M., Messner, S. \& Staff of TENDER (2010). Heartbeat: Relationships without violence. (12.07.2016 tarihinde http://nane.hu/wp-content/ uploads/2016/03/Manual_heartbeat_relationships_without_violence.pdf adresinden alınmıştır.)

Krajewski, S. S., Rybarik, M. F., Dosch, M. F., \& Gilmore, G. D. (1996). Results of a curriculum intervention with seventh graders regarding violence in relationships. Journal of Family Violence, 11(2), 93-112.

Kuffel, S. W., \& Katz, J. (2002). Preventing physical, psychological and sexual aggression in college dating relationships. The Journal of Primary Prevention, 22(4), 361-374.

Lavoie, F., Vezina, L., Piche, C., \& Boivin, M. (1995). Evaluation of a prevention program for violence in teen dating relationships. Journal of Interpersonal Violence, 10(4), 516-524.

Leisring, P. A. (2013). Physical and emotional abuse in relationships: Motivation for perpetration among college women. Journal of Interpersonal Violence, 28(7), 1437-1454.

Lyness, A. M. P., \& Lyness, K. P. (2007). Feminist issues in couple therapy. Journal of Couple \& Relationship Therapy, 6(1-2), 181-195.

McGowan, M. J. (1997). An evaluation of a dating violence prevention program for middle school students. Violence and Victims, 12(3), 223-235.

Meyer, H., \& Stein, N. (2004). Relationship violence prevention education in schools: What's working, what's getting in the way, and what are some future directions. American Journal of Health Education, 35(4), 198-204.

Murphy, C. M., \& Hoover, S. A. (1999). Measuring emotional abuse in dating relationships as a multifactorial construct. Violence and Victims, 14(1), 39-53.

Murray, C. E., \& Kardatzke, K. N. (2007). Dating violence among college students: Key issues for college counselors. Journal of College Counseling, 10(1), 79-89.

Nation, M., Crusto, C., Wandersman, A., Kumpfer, K. L., Seybolt, D., Morrissey-Kane, E., \&Davino, K. (2003). What works in prevention: Principles of effective prevention programs. American Psychologist, 58(6-7), 449-456.

Ntinapogias, A. Petroulaki, K., \& Tsirigoti, A. (2011). Master "GEAR against IPV" Booklet I: Master
Package and How to Develop Your Own "GEAR against IPV" National Package. Athens: European Anti-Violence Network.

O'Leary, K. D., Woodin, E. M., \& Fritz, P. A. T. (2006). Can we prevent the hitting: Recommendations for preventing intimate partner violence between young adults. Journal of Aggression, Maltreatment and Trauma, 13(3-4), 121-178.

Oswalt, S. B., Wyatt, T. J., \& Ochoa, Y. (2018). Sexual assault is just the tip of the iceberg: Relationship and sexual violence prevalence in college students. Journal of College Student Psychotherapy, 32(2), 93-109.

Özdere, M., \& Kürtül, N. (2018). Flört şiddeti eğitiminin üniversite öğrencilerinin flört şiddetine ilişkin tutumlarına etkisi. Social Science Development Journal, 3, 123-136.

Papp, L. J., Liss, M., Erchull, M. J., Godfrey, H., \& Waaland-Kreutzer, L. (2017). The dark side of heterosexual romance: Endorsement of romantic beliefs relates to intimate partner violence. Sex Roles, 76(1-2), 99-109.

Pearson, M. F. (2004). Love U2: Communication Smarts for All Relationships. Berkeley, CA: Dibble Fund for Marriage Education.

Pittman, A. L., Wolfe, D. A., \& Wekerle, C. (2000). Strategies for evaluating dating violence prevention programs. Journal of Aggression, Maltreatment and Trauma, 4(1), 217-238.

Price, E. L., Byers, S., Belliveau, N., Bonner, R.,Caron, B., Doiron, D., Greenough, J., Guerette-Breau, A., Hicks, L., Landry, A., Lavoie, B., Layden-Oreto, M., Legere, L., Lemieux, S., Lirette, M. B., Maillet, G., McMullin, C., \& Moore, R. (1999). The attitudes towards dating violence scales: Development and initial validation. Journal of $\mathrm{Fa}$ mily Violence, 14(4), 351-375.

Reed, L. A., Tolman, R. M., \& Ward, L. M. (2016). Snooping and sexting: Digital media as a context for dating aggression and abuse among college students. Violence against Women, 22(3), 1-21.

Rusbult, C. E., \& Zembrodt I. M. (1983). Responses to dissatisfaction in romantic involvements: A multidimensional scaling analysis. Journal of Experimental Social Psychology, 19(3), 274-293.

Rusbult, C. E., Verette, J., Whitney, G. A., Slovik, L. F., \& Lipkus, I. (1991). Accommodation processes in close relationships: Theory and preliminary empirical evidence. Journal of Personality and Social Psychology, 60(1), 53-78.

Sakall1-Uğurlu, N. (2002). Çelişik duygulu cinsiyetçilik ölçeği: Geçerlik ve güvenirlik çalışması. Türk Psikoloji Dergisi, 17(49), 47-58. 
Sakall1-Uğurlu, N., \& Akbaş, G. (2013). Namus kültürlerinde "namus" ve "namus adına kadına şiddet": Sosyal psikolojik açıklamalar. Türk Psikoloji Yazllart, 16(32), 76-91.

Sakall1-Uğurlu, N., \& Ulu, S. (2003). Evlilikte kadına yönelik şiddete ilişkin tutumlar: Çelişik duygulu cinsiyetçilik, yaş, eğitim ve gelir düzeyinin etkileri. Türk Psikoloji Yazıları, 6(11), 53-65.

Selçuk, K. T., Avcı, D., \& Mercan, Y. (2018). Üniversite öğrencilerinde flört şiddetine maruziyet: Flört şiddetine yönelik tutumların ve toplumsal cinsiyet algısının şiddete maruziyet ile ilişkisi. Acıbadem Üniversitesi Să̆lık Bilimleri Dergisi, 9(3), 302308.

Schwartz, J. P., Magee, M. M., Griffin, L. D., \& Dupuis, C. W. (2004). Effects of a group preventive intervention on risk and protective factors related to dating violence. Group Dynamics: Theory, Research and Practice, 8(3), 221-231.

Schwartz, J. P., Griffin, L. D., Russel, M. M., \& Frontaura-Duck, S. (2006). Prevention of dating violence on college campuses: An innovative program. Journal of College Counseling, 9(1), 90-96.

Shorey, R. C., Cornelius, T. L., \& Bell, K. M. (2008). A critical review of theoretical frameworks for dating violence: Comparing the dating and marital fields. Aggression and Violent Behavior, 13(3), 185-194.

Straus, M. A. (1979). Measuring intrafamily conflict and violence: The Conflict Tactics (CT) Scales. Journal of Marriage and Family, 41(1), 75-88.

Straus, M. A., Hamby, S. L., Boney-McCoy, S., \& Sugarman, D. B. (1996). The Revised Conflict Tactics Scales (CTS2): Development and preliminary psychometric data. Journal of Family Issues, 17(3), 283-316.

Straus, M. A. (2004). Cross-cultural reliability and validity of the revised conflict tactics scale: A study of university student dating couples in 17 nations. Cross-Cultural Research, 38(4), 407-432.

Sunar, D. \& Fişek G. O. (2005). Contemporary Turkish families. İçinde J. L. Roopnarine \& U. P. Gieler (Ed.), Families in Global Perspective (syf. 169183). Boston: Pearson/Allyn and Bacon.

Taluy, N. (2013). Íkili ilişkilerde mükemmeliyetçilik ve çatışma çözme tepkileri: Yatırım modeli çerçevesinde yapılan bir çalışma. Yayınlanmış doktora tezi, Ankara Üniversitesi, Ankara, Türkiye.

Taylor, B. G., Stein, N. D., Mumford, E. A., \& Woods, D. (2013). Shifting boundaries: An experimental evaluation of a dating violence prevention program in middle schools. Prevention Science, 14(1), 64-76.
Teten, A. L., Ball, B., Valle, L. A., Noonan, R., \& Rosenbluth, B. (2009).Considerations for the definition, measurement, consequences, and prevention of dating violence victimization among adolescent girls. Journal of Women's Health, 18(7), 923927.

Theriot, M. T. (2008). Conceptual and methodological considerations for assessment and prevention of adolescent dating violence and stalking at school. Children \& Schools, 30(4), 223-233.

Toplu-Demirtaş, E., Hatipoğlu-Sümer, Z., \& White, J. W. (2013). The relation between dating violence victimization and commitment among Turkish college women: Does the investment model matter? International Journal of Conflict and Violence, 7(2), 203-2015.

Weisz, A. N., \& Black, B. M. (2001). Evaluating a sexual assault and dating violence prevention program for urban youths. Social Work Research, 25(2), 89-100.

Wekerle, C., \& Wolfe, D. A. (1999). Dating violence in mid-adolescence: Theory, significance, and emerging prevention initiatives. Clinical Psychology Review, 19(4), 435-456.

Wekerle, C., \& Tanaka, M. (2010). Adolescent dating violence research and violence prevention: An opportunity to support health outcomes. Journal of Aggression, Maltreatment and Trauma, 19(6), 681-698.

Wolfe, D. A., Wekerle, C., Gough, R., Reitzel-Jaffe, D., Grasley, C., Pittman, A., Lefebvre, L., \& Stumpf, J. (1996). The Youth Relationships Manual: A Group Approach with Adolescents for the Prevention of Women Abuse and the Promotion of Healthy Relationships. Thousand Oaks, CA: Sage.

Wolfe, D. A., Wekerle, C., Scott, K., Straatman, A. L., Grasley, C., \& Reitzel-Jaffe, D. (2003). Dating violence prevention with at-risk youth: A controlled outcome evaluation. Journal of Consulting and Clinical Psychology, 71(2), 279-291.

Wolfe, D.A., Crooks, C., Jaffe, P., Chiodo, D., Hughes, R., Ellis, W., Stitt, L., \& Donner, A. (2009). A school-based program to prevent adolescent dating violence: A cluster randomized trial. Archives of Pediatrics and Adolescent Medicine Journal, 163(8), 692-699.

World Health Organization. (2010). Preventing intimate partner and sexual violence against women: Taking action and generating evidence. (15.07.2016 tarihinde http://www.who.int/violence injury_prevention/publications/violence/9789241564007 eng.pdf adresinden alınmıştir.) 
Violence Prevention Alliance. (2012). Global campaign for violence prevention: Plan of action for 2012-2020. (15.07.2016 tarihinde http://www. who.int/violence_injury_prevention/violence/ global_campaign/gcvp_plan_of_action.pdf?ua=1 adresinden alınmıştır.)

Y1ldırım, S. (2016). Üniversite öğrencilerinin benlik saygisl ve toplumsal cinsiyet tutumlarının flört şiddetine yönelik tutumlarına etkisi. Yayınlanmamış yüksek lisans tezi, Hacettepe Üniversitesi, Ankara, Türkiye.

Yumuşak, A. (2013). Üniversite ögrencilerinin flört şiddetine yönelik tutumlarl, toplumsal cinsiyetçilik ve narsisistik kişilik özellikleri arasındaki ilişki. Yayınlanmış yüksek lisans tezi, Gaziosmanpaşa Üniversitesi, Tokat, Türkiye.

Yumuşak, A., \& Şahin, R. (2014). Flörtte şiddete yönelik tutum ölçeklerinin güvenirlik ve geçerlik çalışması. Elektronik Sosyal Bilimler Dergisi, 13, 233-252. 


\title{
Summary \\ Equality, Safety, Autonomy in Relationships: Testing the Effectiveness of a Dating Violence Prevention Program for College Students
}

\author{
An1l Özge Üstünel \\ İstanbul Bilgi University
}

\begin{abstract}
Dating violence is a serious psychological and social issue influencing the lives of many adolescents and young adults (Murray \& Kardatzke, 2007). Research shows that young people report high rates of dating violence perpetration and victimization across many countries (WHO, 2010) and in Turkey (Aba, 2008; Arslan, 2002; Besni, 2011), and that experiences of abuse are associated with academic, psychological and physical health risks (Dikmen, Özaydın, \& Y1lmaz, 2018; Eshelman \& Levendosky, 2012; Foshee et al., 2013; Oswalt, Wyatt, \& Ochoa, 2018; Teten et al., 2009). A review of the literature shows that dating violence prevention programs targeting middle school, high school and college students can be effective in decreasing violence perpetration (Foshee et al., 1998, 2004, 2005; Wolfe et al., 2003, 2009), in improving an array of emotional and interpersonal skills such as anger control and conflict resolution (Ball et al., 2012; Foshee et al., 1998, 2000; Schwartz et al., 2004) and in challenging violence-supportive and sexist attitudes (Antle et al., 2011; Avery-Leaf et al., 1997; Foshee et al., 1998, 2000, 2005; Krajewski et al., 1996; Kuffel \& Katz, 2002; Schwartz et al., 2004). Although questions have been raised about whether such positive outcomes could be retained in the long run (Cornelius \& Resseguie, 2007) and whether the programs have unitary effects on young men and women (Elias-Lambert, Black, \& Sharma, 2010), prevention programs seem to be a promising strategy to eliminate violence from dating and intimate relationships (Violence Prevention Alliance, 2012).

In Turkey, studies conducted with college students reveal that dating violence is a common problem (Hüsnü \& Mertan, 2017; Sakall1-Uğurlu \& Ulu, 2003; Toplu-Demirtaş, Hatipoğlu-Sümer \& White, 2013) and that
\end{abstract}

interventions which aim to raise awareness about dating violence are needed (Aslan et al., 2008; Kılınçer \& Tuzgöl-Dost, 2014; Selçuk et al., 2018; Yıldırım, 2016). However, research on this topic is surprisingly scarce. The present study aims to fill this gap by designing a dating violence prevention program for college students attending a university in Istanbul and testing its effectiveness. Towards this goal, the following hypotheses were tested: Participants in the prevention group would report a) more constructive conflict resolution skills in relationships, b) less support for ambivalent sexism and c) less supportive attitudes for dating violence after the program. The effect of sex was examined for each hypothesis in order to explore whether the program influenced young men and women differently.

\section{Method}

\section{Program Development}

An early version of a dating violence prevention program was developed with the aim of enhancing the students' knowledge of various forms of violence and control, providing guidance for establishing safe and equal relationships, and improving their relational skills. In the designing phase, individual interviews with 19 college students were conducted and available prevention programs (Koberlein et al., 2010; Ntinapogiaset al., 2011; Tsirigoti et al., 2011; Wolfe et al., 1996) were reviewed. Informed by feminist clinical approaches (Aronson \& Buchholz, 2001; Enns, 1992; Goldner, 1998, 1999, 2004; Knudson-Martin, 2013; Lyness \& Lyness, 2007), the initial program involved 8 sessions with awareness-raising, psycho-education and skill-development components.

Address for Correspondence: Asst. Prof. Anıl Özge Üstünel, İstanbul Bilgi University, Faculty of Social Sciences and Humanities, Department of Psychology, Santralistanbul, Eski Silahtarağa Elektrik Santrali, Kazım Karabekir Cad., No: 2/13, 34060, Eyüpsultan / İstanbul

E-mail: anil.ustunel@gmail.com 


\section{Pilot Study}

After obtaining ethical approval for the study, a pilot study was conducted to test whether the program worked efficiently. Two pilot groups were organized and the following revisions were made based on the participants' feedback and the author's observations: 1) Decreasing the number of activities per session, 2) Exploring personal experiences through role plays, 3) Adding weekly assignments, 4) Preparing and sharing informative brochures.

\section{Main Study}

\section{Procedure}

The program was advertised via e-mails and posters to recruit participants for the main study. For the prevention group, 4 mixed-sex groups were formed and the students were invited to a meeting session in order to provide information. Those who agreed to participate completed the pre-test assessment and attended the 8 -session program. The post-test assessment was carried out at the last session. The control group did not receive any intervention. They were invited to the pre-test and post-test assessments via e-mail. Both groups gained extra course credits for their participation.

\section{Participants}

The final sample consisted of 41 participants (24 women, $17 \mathrm{men}$ ) who completed the program in the prevention group and 49 participants (25 women, 24 men) who completed both assessments in the control group. The age range of the overall sample was 18-22.

\section{Instruments}

A series of data collection instruments were used in the present study. These instruments included 1) the Revised Conflict Tactics Scale (CTS2), developed by Straus and colleagues (Straus, 1979; Straus et al., 1996) and adapted for Turkish use by Aba (2008); 2) Responses to Dissatisfaction Scale (RDS), developed by Rusbult and colleagues (Rusbult et al., 1991; Kilpatrick, Bissonnette, \& Rusbult, 2002) and adapted for Turkish use by Taluy (2013); 3) Ambivalent Sexism Inventory (ASI), developed by Glick and Fiske (1996) and adapted for Turkish use by Sakall1-Ugurlu (2002); 4) Attitudes towards Dating Violence Scales (ADVS), developed by Price and colleagues (1999) and adapted for Turkish use (Yumusak, 2013); 5) A socio-demographic information form developed by the author.

\section{Results}

Preliminary analyses revealed no significant differences between the prevention and control group with regards to dating history, experiences of dating violence and pre-test scores. A series of 2 (Time: pre-test, posttest) x 2 (Group: prevention, control) x 2 (Sex: women, men) mixed factorial ANOVAs were carried out to test the hypotheses.

\section{The Effect of the Program on Conflict Resolution}

With regards to RDS scores, the analysis showed that two and three-way interaction effects were non-significant.

\section{The Effect of the Program on Sexist Attitudes}

With regards to ASI-hostility scores, the analysis revealed a significant Time $\mathrm{x}$ Group interaction, $\mathrm{F}_{1,86}=$ $5.81, p=.02$, partial $\eta^{2}=.06$. The results showed that the ASI scores of the prevention group was higher at pretest $(M=2.48, S D=1.10)$ than post-test $(M=2.19, S D=$ 1.02), while for the control group there was no difference between pre-test $(M=2.72, S D=1.08)$ and post-test ASI scores $(M=2.69, S D=1.07)$. Other interaction effects were found to be non-significant.

The analysis on ASI-benevolence scores showed that two and three-way interaction effects were statistically non-significant.

\section{The Effect of the Program on Attitudes towards Dating Violence}

With regards to ADVS-male physical violence scores, the analysis revealed non-significant two and three-way interaction effects.

The analysis on ADVS-female physical violence scores showed a significant Time $\mathrm{x}$ Group interaction, $\mathrm{F}_{1,85}=5.94, p=.02$, partial $\eta^{2}=.06$. The ADVS-female physical violence scores in the prevention group was higher at pre-test $(M=1.69, S D=0.69)$ than post-test $(M$ $=1.35, S D=0.47$ ), while for the control group there was no difference between pre-test $(M=1.57, S D=0.58)$ and post-test scores $(M=1.47, S D=0.52)$. Other interaction effects were found to be non-significant.

With regards to ADVS-male psychological violence scores, the analysis revealed a significant Time $\mathrm{x}$ Group interaction, $\mathrm{F}_{1,85}=5.09, p=.03$, partial $\eta^{2}=.06$. The ADVS-male psychological violence scores in the prevention group was higher at pre-test $(M=1.81, S D=$ $0.50)$ than post-test $(M=1.62, S D=0.46)$, while for the control group there was no difference between pre-test $(M=1.69, S D=0.48)$ and post-test scores $(M=1.64$, $S D=0.48)$. Other interaction effects were found to be non-significant.

The analysis on ADVS-female psychological violence scores showed that two and three-way interaction effects were statistically non-significant. 


\section{Discussion}

The present study aimed to test the effectiveness of a dating violence prevention program in a sample of college students in Istanbul, Turkey. The first hypothesis which posited that the program would improve constructive conflict resolution skills was not supported. This finding contradicts with prior research reporting positive changes in interpersonal skills after participating in a dating violence prevention program (Ball et al., 2012; Foshee et al., 1998, 2000). One reason for this contradiction could be the insufficiency of the present program in terms of its length, content and activities. As suggested by previous researchers (Ball et al., 2012; Foshee et al., 1998, 2000; Nation et al., 2003), a more intensive approach with longer sessions and multi-level intervention components could be more effective in producing the desired behavioral changes. Another reason could be related to the methodological limitations of the present study. Detecting changes in conflict resolution skills proved to be difficult because some participants did not experience any significant conflicts with their partners or friends between the pre-test and post-test assessments. In future work, designing longitudinal studies with longer follow-up periods and utilizing multiple sources of information might help to overcome these limitations (O'Leary et al., 2006; Wekerle \& Tanaka, 2010).

The hypothesis that the present program would decrease sexist attitudes found partial support. Consistent with previous studies (Foshee et al., 1998, 2000; Schwartz et al., 2004, 2006), the results showed a decrease in hostile sexism in the prevention group. Most participants in the present study reported that working in a mixed-sex setting contributed to this change by preventing polarization and providing a new socialization context. This finding is parallel to the studies which report that young people tend to prefer mixed-sex settings (Elias-Lambert, Black \& Sharma, 2010) and enjoy learning each other's viewpoints (Kerig et al., 2010). On the other hand, no significant change was observed in benevolent sexism after the program. One explanation is that benevolent sexism is interpreted as positive since it incorporates men's possessive and protective attitudes (Glick \& Fiske, 1996; Glick et al., 2000) which are idealized and romanticized in the name of love (Jackson, 2001; Johnson et al., 2005). Increasing awareness about the power inequality inherent in these attitudes and challenging them might require a more intensive intervention.

The last hypothesis that the present program would decrease accepting attitudes towards dating violence found partial support. Firstly, the results showed a significant decrease only in the acceptance of female-perpetrated physical violence, paralleling Jaycox and col- leagues' findings (2006). The lack of change in attitudes towards men's use of physical violence might indicate a floor effect, because some participants reacted very negatively to relevant items of the scale and expressed that the items were not suitable to the college context. Secondly, the results revealed a significant decrease only in the acceptance of male-perpetrated psychological violence. This change is consistent with the decrease found in hostile beliefs about women, because both normalize and justify men's dominance and control over women. The lack of change in attitudes towards women's use of psychological violence might indicate that more time needs to be devoted to this topic since recognizing psychologically abusive behavior is more difficult as compared to other forms of violence (Murphy \& Hoover, 1999). In addition, women may resort to psychological violence for various reasons such as anger, jealousy and self-defense (Leisring, 2013). Capturing the diversity in these experiences and addressing them might increase the effectiveness of the program in future work.

The present study had some limitations. Firstly, the participants could not be randomly assigned to the prevention and control group because of the high drop put rate and the time restraint during recruitment. Secondly, a follow-up study could not be carried out to learn about the participants' experiences in the long run. Thirdly, the program was implemented at a single university and a majority of the group members were women. These factors limited the generalizability of the results. Fourthly, some participants reported that they were motivated by external rewards such as course credits rather than a willingness to learn about the group topics. Their presence influenced and changed group dynamics. Lastly, potential biases in self-report measures (i.e. experimenter expectancy bias), should be taken into account when interpreting the results. Future dating violence prevention efforts will hopefully overcome these limitations and incorporate more effective practices to ensure safety and equality in dating relations. 